\title{
edoc
}

Institutional Repository of the University of Basel

University Library

Schoenbeinstrasse 18-20

CH-4056 Basel, Switzerland

http://edoc.unibas.ch/

Year: 2012

\section{The Magdalenian in Switzerland: re-colonization of a newly accessible landscape}

Leesch, Denise and Müller, Werner and Nielsen, Ebbe and Bullinger, Jérôme

Posted at edoc, University of Basel

Official URL: http://edoc.unibas.ch/dok/A6070388

Originally published as:

Leesch, Denise and Müller, Werner and Nielsen, Ebbe and Bullinger, Jérôme. (2012) The Magdalenian in Switzerland: re-colonization of a newly accessible landscape. Quaternary international, 272-273. S. 191-208. 


\section{Elsevier Editorial System(tm) for Quaternary International Manuscript Draft}

Manuscript Number: QUATINT-D-12-00069R1

Title: The Magdalenian in Switzerland: re-colonization of a newly accessible landscape Article Type: Magdalenian Settlement of Europe

Keywords: Magdalenian; Switzerland; Late Glacial; resettlement

Corresponding Author: Dr Denise Leesch,

Corresponding Author's Institution: Institut d'archéologie

First Author: Denise Leesch

Order of Authors: Denise Leesch; Werner Müller; Ebbe Nielsen; Jérôme Bullinger 


\section{Quaternary International}

We the undersigned declare that this manuscript is original, has not been published before and is not currently being considered for publication elsewhere.

We confirm that the manuscript has been read and approved by all named authors and that there are no other persons who satisfied the criteria for authorship but are not listed. We further confirm that the order of authors listed in the manuscript has been approved by all of us.

We understand that the Corresponding Author is the sole contact for the Editorial process. $\mathrm{He} / \mathrm{she}$ is responsible for communicating with the other authors about progress, submissions of revisions and final approval of proofs.

Signed by all authors as follows: Denise Leesch, Werner Müller, Ebbe Nielsen, Jérôme Bullinger 


\title{
The Magdalenian in Switzerland: re-colonization of a newly accessible landscape
}

\author{
Denise Leesch $^{\mathrm{a}^{*}}$, Werner Müller $^{\mathrm{a}}$, Ebbe Nielsen $^{\mathrm{b}}$, Jérôme Bullinger ${ }^{\mathrm{c}}$ \\ a Université de Neuchâtel, Laboratoire d'archéozoologie, avenue de Bellevaux 51, CP 158, CH-2009 Neuchâtel, Switzerland \\ $\mathrm{b}$ Archaeological Survey of the canton of Lucerne, Libellenrain 15, CH-6002 Luzern, Switzerland \\ c Musée cantonal d'archéologie et d'histoire, Place de la Riponne 6, CH-1014 Lausanne, Switzerland \\ *corresponding author
}

\begin{abstract}
During the Last Glacial Maximum, Switzerland was almost entirely covered with ice. However, in the ice-free region situated less than $50 \mathrm{~km}$ north of the glaciers, human occupation is confirmed as early as $23000 \mathrm{cal}$ BP. Numerous sedimentary sequences in lakes and mires have produced a wealth of proxy data indicating that environmental conditions improved rapidly after the melting of the glaciers that liberated the Swiss Plateau at least at $c .17500 \mathrm{cal} \mathrm{BP}$, offering severe but possible life conditions to plant, animal and human communities. Contrary to what has long been the prevailing opinion, Magdalenian re-colonization of Switzerland did not start with the onset of the warming of Greenland Interstadial 1e, but well before. According to most of the recently obtained AMS-dates, the Magdalenian occupation falls within the cold, treeless, environment of the Oldest Dryas period; it is even conceivable that it did not extend into Greenland Interstadial 1e. More than 50 sites, among which famous caves and rockshelters such as Kesslerloch and Schweizersbild, as well as large open-air campsites like Monruz and Moosbühl, have produced different techno-assemblages that find good comparisons in the rest of Europe. In contrast to the exploitation of mainly local and regional flint sources, the use of "exotic" ornamental/symbolic objects - fossil mollusks, amber and jet - shows widespread, multidirectional long-distance connections with the upper Danube basin, the Mainz basin, the Paris Basin, the Atlantic coast, the Mediterranean and even the Baltic regions.
\end{abstract}

Keywords: Magdalenian, Switzerland, Late Glacial, resettlement

\section{Introduction}

Before the discovery of the open-air sites Champréveyres and Monruz in the 1980s, it was generally accepted that Magdalenian colonization of Switzerland, expanding from southwest France, had taken place only in a late stadium of the Late Glacial, meaning the Bølling/Allerød Interstadial. This model was based on many erroneous conventional radiocarbon dates that were obtained during the 1970s and early 1980s (Sedlmeier, 1989, p. 196; Höneisen et al., 1993, p. 201) and on the assumption that resettlement would have had to be concurrent with climate warming. The problematic radiocarbon determinations also suggested that the different Magdalenian techno-assemblages were even partially contemporaneous with Azilian industries. At the present state of research, it has become clear that Magdalenian occupation can be correlated with the still cold period of Greenland Stadial GS-2 (GS-a and GS-b) and that this techno-complex probably ended with the climatic amelioration of the Greenland Interstadial GI-1e. Evidence from Champréveyres and Monruz demonstrates indeed that the Azilian was established on the Swiss Plateau from at least 12300 BP (c. 14400 cal BP) onwards (Leesch et al., 2004). The aim of this contribution is to present some of the new radiocarbon dates supporting the idea that Switzerland was colonized independently from temperature but in relation with the development of the vegetation cover and the density of horse and reindeer populations.

\section{Topographical characteristics of Switzerland}

Switzerland, with a surface area of $c .41000 \mathrm{~km}^{2}$, consists of three large topographical entities: the Alps, taking up the southern half of the country with the central chain exceeding $4000 \mathrm{~m}$, the Jura mountain chain in the northwest with its highest peaks reaching $1600 \mathrm{~m}$, and finally the Swiss Plateau, extending between these two mountain ranges from Lake Geneva to Lake Constance with an average altitude of 400-600 m (Fig. 1). As a consequence of these topographic features, the Swiss Plateau got filled up with ice during periods of glaciations, for the most part from the Rhone-Aare and Rhine-Linth-Reuss glaciers (e.g. Ehlers and Gibbard, 2004). With the decay of the ice cover the areas became available for resettlement. Thus, Switzerland may serve as a model for the process of re-colonization of temporally inhabitable landscapes.

\section{The Last Glacial Maximum}

The exact extent of the glaciers during their last maximum expansions has been refined in a recent up-date of the LGM map of Switzerland by a group of researchers (Bini et al., 2009). While these data can be regarded as satisfactorily precise and are by and large accepted, the exact chronology of the LGM remains controversial (e.g. Schoeneich, 2003; Ivy-Ochs et al., 2004; Preusser, 2004; Svensson et al., 2006; Ivy-Ochs et al., 2008; Schoeneich et al., 2011). This might not the least stem from the fact that some researchers define the LGM based solely on a temperature curve derived from different ocean or ice core drilling projects, while for others the LGM designates the time of the largest extent of the glaciers (either globally or locally, e.g. for the Alps), 
therefore of a time period where several factors must coincide, like low temperatures, high amounts of precipitation, low snow line, etc. For the present article, we follow Ivy-Ochs et al. (2004) who dated the largest extent of the Solothurn lobe of the Rhone piedmont glacier. According to these authors, "the maximum extent [...] was contemporaneous with the world wide ice maximum between 24 and $19 \mathrm{ka}$ " and the "break down of the Rhone piedmont glacier system occurred between 21.1 and $19.1 \mathrm{ka}$ ". It has to be visualized that e.g. in the Rhone valley at the location of present day Martigny, ice thickness must have exceeded $2000 \mathrm{~m}$ (Kelly et al., 2004), and in the area of Lake Neuchâtel, the ice sheet still had a thickness of over $600 \mathrm{~m}$ (Bini et al., 2009). Obviously, the expansion of the glaciers not only eradicated any signs of previous occupations in that area but also inhibited any form of life, be it plant or animal. Yet away from the glaciers, living conditions might have been extreme but not impossible.

In the northwestern corner of Switzerland (close to Basel) two caves yield proof of human occupation: Kastelhöhle Nord and Y-Höhle (Fig. 2). The middle archaeological layer of Kastelhöhle Nord, excavated in 1948, has produced a small lithic assemblage of 228 objects assigned to the Badegoulian (Fig. 3). It is characterized by a large number of splintered pieces and no blade production. Raw material is diverse and mostly of regional origin (less than $40 \mathrm{~km}$ ), except for 4 pieces that come from $100 \mathrm{~km}$ to the southwest (Affolter, in Sedlmeier 2010). This composition shows that the people living in this area were exploiting the same resources that were used later during Magdalenian periods. From the faunal remains associated with the industry three reindeer bones from which two bear cut marks, have produced $\mathrm{AMS}{ }^{14} \mathrm{C}$ dates of $18530 \pm 150 \mathrm{BP}$, $19200 \pm 150 \mathrm{BP}$ and $19620 \pm 140 \mathrm{BP}$ (Terberger and Street, 2002; Sedlmeier, 2010). The second cave, "YHöhle", yielded only a single reindeer bone with cut marks (Fig. 4); this bone has been dated to $18875 \pm 115 \mathrm{BP}$ (Sedlmeier, 2010). Even though this element is in secondary position and was probably washed into the cave from the surface above, it is proof for a human occupation at that time. Both occupations date therefore to a calibrated age between 22100 and 23400 years cal BP which places them into or right after the end of the LGM, depending on the reference used. It has indeed been speculated that this early colonization of the area was made possible by or linked to the brief warming phase of the GI-2 (Terberger and Street, 2002; Sedlmeier, 2010); yet the contemporaneity of this relatively short phase of about 700 years with the obtained dates remains open to discussion. It should be noted that the caves are located at the northern border of the Jura Mountain in valleys facing away from the alpine glaciers so that the Jura mountain range might have had in a way a "protective effect" and allowed a milder microclimate as compared to the southern flank of the Jura. Nevertheless, with these two occupations in Switzerland and some other sites in Germany (Terberger and Street, 2002), it is established that the region north of the Alps was not completely depopulated at that time, even though population density was probably rather low.

\section{The ice decay}

The precise chronology of the ice decay is still debated, yet the rough time frame seems to be generally accepted: ice collapse was rather rapid, breakdown of the Rhone piedmont glacier system started possibly right at, or shortly after reaching its maximum extent at 21000 cal BP, but no later than $c$. 19100 cal BP (Ivy-Ochs et al., 2004; Ivy-Ochs et al., 2008). Already at 17500 cal BP, the entire Alpine foreland was ice-free and major environmental changes can be observed in many lakes and mires (Schoeneich, 2003). Records exist for example for Lake Constance (Wessels, 1998a and b), Lake Zurich (Lister, 1988) and Lake Neuchâtel (Hadorn et al., 2002; Magny et al., 2003; Thew et al., 2009). The newly accessible, glacier-shaped landscape was characterized by many lakes and mires and by an absence of top soil, so that the recolonization by plants must have been slow at the beginning and could only be achieved by pioneer vegetation capable of growing on mineral soils. Many sedimentary sequences preserved in those lakes, ponds and mires at various altitudes were analyzed for palaeoecological studies, thus making this region one of the best studied areas for the Late Glacial and Holocene in Europe (e.g. Lang, 1985; Burga and Perret, 1998; Richard and Bégeot, 2000).

\section{Late Glacial vegetation and climate history}

Some of the most detailed studied lakes and mires for the reconstruction of the Late Glacial vegetation and climate history of this area are (see Fig. 1): Lobsigensee (Ammann, 1989; Elias and Wilkinson, 1983), GrandMarais (Gaillard, 1984 ; Gaillard and Lemdahl, 1994) Soppensee (Lotter et al., 1992a; Lotter, 1999), Rotsee (Ammann and Lotter, 1989; Lotter, 1991; Verbruggen et al., 2010), Aegelsee (Lotter et al., 1992b;Wehrli et al., 2007), Gerzensee (Lotter et al., 2000; Schwander et al., 2000; Lotter et al., 1992b), Lake Chalain (Wegmüller, 1966), Lake Cerin (Ruffaldi, 1993, 1996) and Lake Lautrey (Heiri and Millet, 2005; Magny et al., 2006). In addition to pollen analysis, those investigations often include the study of plant macrofossils, diatoms, beetles, chironomids, mollusks and in several cases also annually laminated sediments. Moreover, stable-isotope investigations allow to correlate the major changes observed in the vegetation with the Greenland Ice-Core Event Stratigraphy (Schoeneich, 2003; Björck et al., 1998; Walker et al., 1999; Lowe et al., 2008). 
In respect to the Magdalenian, the palaeoenvironmental research conducted at Hauterive/Rouges-Terres is of particular importance. This study concerns a section of $150 \mathrm{~m}$ that has been documented during the construction of a motorway along Lake Neuchâtel and is situated only $500 \mathrm{~m}$ east of the Magdalenian campsite Champréveyres (Magny et al., 2003; Thew et al., 2009). The section allowed high resolution analyses of the pollen, plant macrofossil, insect and mollusk record, notably for a well developed sedimentary sequence of the Oldest Dryas. Moreover, the sequence being rich in organic matter, 87 AMS radiocarbon dates were obtained from plant remains, and thus constitutes a major reference stratigraphy for the early phase of the Late Glacial. Interestingly, the radiocarbon dates show several ${ }^{14} \mathrm{C}$ plateaus of constant age, notably one at $c$. $12600-12400$ $\mathrm{BP}$, relevant for the Magdalenian-Azilian transition, and another one at c. 12200-12000 BP (Hajdas and Bonani, 2009).

Late Glacial vegetation history of the of the Swiss Plateau has been divided into four regional pollen assemblage zones (RPAZ) termed as CHb-1, CHb-2, CHb-3 and CHb-4 (Lotter et al., 1992a; Ammann et al., 1996). The first zone, $\mathrm{CHb}-1$, equivalent to the Late Pleniglacial/Oldest Dryas biozone, is the most relevant stage for understanding the re-colonization process by Magdalenian populations and covers the time span from the decay of the glaciers to the onset of the Bølling biozone. Zone $\mathrm{CHb}-2$ corresponds to the start of the Bølling biozone and is correlated with GI-1e. At the present state of research, it is not established whether the Magdalenian extends into this latter zone or whether the Azilian starts at that time. Zone $\mathrm{CHb}-3$ corresponds to a later phase of the Bølling biozone and to the expansion of the Azilian. These three regional pollen assemblage zones and subzones can be characterized as follows (Fig. 5):

RPAZ CHb-1, Artemisia-PAZ (Late Pleniglacial/Late Glacial/Oldest Dryas biozone/Greenland Stadial GS$2 \mathrm{a} / \mathrm{b})$

This zone is subdivided into three subzones termed as $\mathrm{CHb}-1 \mathrm{a}, \mathrm{CHb}-1 \mathrm{~b}$ and $\mathrm{CHb}-1 \mathrm{c}$.

CHb-1a (Artemisia-Pinus sub-PAZ; $>17500$ cal BP): The onset of this zone is not well defined because of the absence of vegetation during a certain time after the ice decay. First plant communities indicate sparse herbaceous pioneer vegetation including heliophilous taxa such as Artemisia, Helianthemum and Dryas octopetala. High values of Pinus in the pollen record are due to long-distance transport whereas significant numbers of pollen from Abies and Picea stem from reworked sediments indicating unstable conditions.

CHb-1b (Artemisia-Helianthemum sub-PAZ; c. 17500-15800 cal BP): The second subzone is characterized by more stabilized conditions (less reworked coniferous pollen of Abies and Picea). Pollen spectra are dominated by an arctic alpine heliophilous flora. Vegetation can be described as grassland with alpine and steppe herbs. A skull from a woolly rhinoceros dated to $13980 \pm 140 \mathrm{BP}(17236 \pm 243 \mathrm{cal} \mathrm{BP})$ that has been recovered from Lake Neuchâtel (Fig. 6; Morel and Hug, 1996) and a nearly complete skeleton of a mammoth dated to $13705 \pm$ 55 BP (16845 \pm 192 cal BP) discovered in the Jura mountain (Hajdas et al., 2007), at an altitude of $1045 \mathrm{~m}$, demonstrate that the plant cover was sufficiently developed to allow large herbivorous animals to graze in this area.

CHb-1c (Artemisia-Betula nana sub-PAZ; c. 15800-14700 cal BP): This subzone is characterized by the expansion of dwarf shrubs such as Betula nana and various low to the ground growing Salix species. During this phase species-rich grassland with dwarf shrub heaths covered the Swiss lowlands and alpine foreland. The campsites Monruz and Champréveyres (Gaillard, 2004) as well as certain occupation layers from the cave Kesslerloch (Ammann et al., 1988) are correlated with this vegetation phase on the basis of pollen analysis.

Palaeotemperatures inferred from coleopteran assemblages (notably in Hauterive/Rouges-Terres and Champréveyres; Coope and Elias, 2000; Coope and Lemdahl, 2009) indicate mean temperature of the warmest month slightly under $10{ }^{\circ} \mathrm{C}$ and mean temperature of the coldest month between -15 and $-20{ }^{\circ} \mathrm{C}$, sometimes even lower. Only towards the end of Oldest Dryas, the mean temperature of the warmest month rose to $c .11^{\circ} \mathrm{C}$ and to c. $-10{ }^{\circ} \mathrm{C}$ for the coldest month.

RPAZ CHb-2, Juniperus-Hippophä̈-PAZ (c. 14700-14400 cal BP) (start of Late Glacial Interstadial/ beginning of Bølling biozone/Greenland Interstadial GI-1e, Meiendorf)

This pollen assemblage zone is marked by a rapid increase of Juniperus communis and Hippophä rhamnoides. It corresponds to the onset of the Bølling biozone correlated to GI-1e and to what is also termed as Meiendorf 
interstadial in northern Germany. The vegetation consists of open shrub and grassland into which some tree birches (Betula pendula and Betula pubescens) are spread.

Temperature estimates reconstructed on the basis of coleopteran assemblages show a rapid rise corresponding to a major episode of warming in both summer and winter temperatures. The mean temperature of the warmest month rises to at least $15{ }^{\circ} \mathrm{C}$ and the mean temperature of the coldest month to $c .0{ }^{\circ} \mathrm{C}$. At the present state of research, no archaeological assemblage in Switzerland is clearly correlated with this short and characteristic vegetation phase.

RPAZ CHb-3, Betula-PAZ (c.14400-13850 cal BP; Late Glacial Interstadial, Bølling biozone, Greenland Interstadial GI-1e/1d/1c)

CHb-3 is a long phase dominated by tree birch (Betula sp.) that can be divided into two subzones: a longer subzone $\mathrm{CHb}-3 \mathrm{a}$ rich in tree birch (Betula sp.), willow (Salix sp.) and characterized by increasing values of poplar (Populus sp.) suggesting still open birch woodland, and a short phase $\mathrm{CHb}-3 \mathrm{~b}$, not always well attested, showing a decrease in Betula associated with an increase in grasses. The latter phase is usually attributed to the classic Older Dryas and indicates still open birch woodland with Juniperus and Salix but no pine trees or only very few. During the later phase of $\mathrm{CHb}-3$, temperature rises up to $c .18^{\circ} \mathrm{C}$ means for the warmest month, while the mean temperature for the coldest month is situated around $0{ }^{\circ} \mathrm{C}$ to $2{ }^{\circ} \mathrm{C}$. The Azilian occupation in Champréveyres is correlated with subzone CHb-3a on the basis of palynological analysis (Gaillard, 2004).

\section{Geographic distribution of the Magdalenian sites}

Strikingly, only few Magdalenian sites have been discovered around the numerous lakes and mires in the morainic lowland areas of the Swiss Plateau and in the Alpine foreland. The same holds true for adjacent southwest Germany where occupations in caves and rockshelters are abundant in the Swabian Alb compared to only few open-air localities in the lowlands of Oberschwaben and in the Rhine valley (Weniger, 1982; Eriksen, 1991). As it is frequently the case in karstic regions, Palaeolithic research in Switzerland has long concentrated on caves and rockshelters since they are much easier to locate than open-air sites. The distribution of the more than 50 Magdalenian sites recorded at present is thus largely attributable to reasons of history of research and does not reflect the primary occupation of the landscape (Fig. 7). As shown by the discovery of Monruz and Champréveyres, the absence of any other sites around Lake Neuchâtel, Lake Bienne and Lake Morat is probably due to the fact that most sites are situated below the present-day lake level of those water bodies. The two vast sites situated on the shore of Lake Neuchâtel were indeed discovered during the construction of a motorway at $c$. $2 \mathrm{~m}$ below the present-day lake level, a depth that can only rarely be investigated under normal circumstances.

The distribution of the open-air sites however clearly indicates that open localities were commonly used alongside caves and rockshelters. Even the cave-free Swiss Plateau was intensively occupied, as shown by the site of Moosbühl, near Bern, the largest Magdalenian campsite known today in Switzerland (Bullinger et al., 1997). In addition to this major site, detailed studies of assemblages collected from surface locations have recently increased the number of known sites and changed the general picture of the Magdalenian occupation in this part of the country (von Burg, 1994; Nielsen, 1999, 2002, 2009). As an example: around the peat bog Wauwilermoos, Magdalenian artefacts are known from 11 locations, major sites being Kottwil-Station 11, Kottwil-Hubelweid and Mauensee-Moos. Another important site discovered only few kilometers northwest of the Wauwil bog is Reiden-Stumpen, located on a sandstone hill (c. $512 \mathrm{~m}$ asl), approximately $50 \mathrm{~m}$ above the present-day valley floor (Nielsen, 1994). The collections from those surface sites show the same technotypological diversity than the assemblages excavated from caves and are thus likely to indicate different chronological Magdalenian occupation phases.

Contrary to the Mesolithic period, for which a large number of sites at high altitudes in the Alps above $1000 \mathrm{~m}$ (Crotti, 1993, 2008; Braillard et al., 2003; Bullinger and Huber, 2010) are documented, during the Magdalenian, altitudes above $c$. $600 \mathrm{~m}$ do not seem to have been occupied, or only in the latest phase. Ecological factors probably limited human expansion into these territories. The topographical setting of the Magdalenian sites thus seems to be essentially correlated with the possibilities for exploiting local vegetation and animal resources.

\section{Diversity of the Magdalenian assemblages}

Most Magdalenian sites of Switzerland have been excavated more than 50 years ago, except for Champréveyres (Leesch, 1997), Monruz (Bullinger et al., 2006), certain sectors of Moosbühl (Bullinger et al., 1997), Rislisberghöhle (Stampfli, 1983) and Chesselgraben (Spycher and Sedlmeier, 1985; Sedlmeier, 1998, pp. 311313). The cave site Rislisberghöhle and the rockshelter Chesselgraben however have not yet been studied and 
published in detail, so that even for these sites that have been excavated quite recently it remains difficult to get a precise idea of the stratigraphic context of the material they contained. It has to be assumed that due to relatively coarse excavation techniques used before 1970, the stratigraphic integrity of most of the assemblages extracted from caves is questionable. Nevertheless, based upon several more or less well individualized archaeological layers and on some sites that yielded only one occupation horizon, a subdivision of the Late Upper Palaeolithic assemblages into five "techno-assemblages" has been proposed some twenty years ago (Leesch, 1993; Le Tensorer, 1998). Because no new stratified assemblages have been excavated since that time, no extra information can be added to the general scheme that was then proposed. For a reminder, the main characteristics of the five assemblages can be summarized as follows:

Techno-assemblage A. This assemblage is known from only one site in Switzerland, from Kastelhöhle Nord (middle layer), a cave that was excavated in 1948/1950. The small assemblage, already presented above (see Fig. 3), contains 228 artefacts characterized by a great number of splintered pieces and does not contain any backed bladelets nor any bone or antler artefacts (Sedlmeier, 2010). Reindeer and arctic hare are represented among the rare faunal remains associated. The assemblage is assigned to the Badegoulian, a typo-technological attribution supported by three radiocarbon determinations around $23000 \mathrm{cal} \mathrm{BP}$.

Techno-assemblage B. The lower archaeological layer of cave Birseck-Ermitage, excavated in 1910, yielded a rich Magdalenian industry containing dihedral burins, scrapers on blades, piercers, backed bladelets and a series of 10 scalene triangles of the type that is usually associated with middle Magdalenian assemblages (Fig. 8; Höneisen et al., 1993, p. 158; Sedlmeier, 1998, p. 302). The bone industry also comprises several baguettes demi-rondes and two double beveled antler points. Wild horse, reindeer, lemming, pika and ground squirrel are represented among the associated faunal remains. The open-air site Kottwil has also produced two scalene triangles associated with various other Magdalenian tools that may indicate the presence of a site belonging to this techno-assemblage on the central Swiss Plateau (Kottwil-Station 14; Nielsen 2002, 191; Nielsen, 2009 , fig. $635,49)$.

Techno-assemblage $\boldsymbol{C}$. Although the cave of Kesslerloch has certainly been re-occupied many times and the assemblage lacks stratigraphic integrity, it is clear from the typo-technological point of view that it contains artefacts belonging to an assemblage that is not represented in most of the other Swiss Magdalenian sites. This assemblage is characterized by a rich antler industry containing points of the Lussac-Angles type and by baguettes demi-rondes à décor de tubérosités, characteristic of the middle Magdalenian (Fig. 9; Höneisen, 1993). The presence of mammoth and woolly rhinoceros among the faunal remains, as well as a little sculpture representing a musk-ox (Fig. 9, 10), also point to a relatively early stage of the Magdalenian, since those animals disappeared from the Swiss Plateau and from southwestern Germany before the end of the Magdalenian (Weniger, 1982). The assemblage of the nearby cave Freudenthal containing also a fragment of a baguette demironde à décor de tubérosités, belongs to the same techno-assemblage. Palynological investigations performed on cores that were drilled in 1980 in front of the Kesslerloch tend to assign certain layers from the base of the sedimentary sequence to the vegetation phase of the expansion of Betula nana, at c. 13000 BP (Ammann et al., 1988). Several AMS radiocarbon dates however point to the existence of older occupation layers (see below).

Techno-assemblage $\boldsymbol{D}(\boldsymbol{D}-\boldsymbol{a}$ and $\boldsymbol{D}-\boldsymbol{b})$. A large number of sites have produced lithic industries dominated by backed bladelets but do not contain enough antler industry to distinguish them from techno-assemblage C. However, all are devoid of angle-backed, curve-backed and shouldered points, which distinguishes them also from techno-assemblage E. These industries concern for example Sählihöhle Oben, Heidenküche, HollenbergHöhle 3, Rheinfelden-Eremitage, Reiden-Stumpen, Champréveyres, Monruz and Moosbühl. Possibly this type of industry must be subdivided into two sub-assemblages D-a and D-b. The assemblages of Champréveyres and Monruz containing more than $50 \%$ of backed bladelets can be taken as the reference assemblages of technoassemblage D-a (Fig. 10), whereas the assemblage of Moosbühl containing significant proportions of truncated backed bladelets, rectangles and longborers is taken as a reference for techno-assemblage D-b (Fig. 11). The beads made from jet found at Mossbühl also differ slightly in shape from those found at Monruz, the former being rather thick and one of them with a bi-conical cross-section (Fig. 11, 53), whereas the latter ones are thin and flat (at Gönnersdorf, however, both types occur together). None of the faunal spectra associated with these assemblages contain mammoth, woolly rhinoceros or musk-ox, and therefore probably post-date the retreat of these species from the Swiss Plateau. Palaeoenvironmental data and radiocarbon ages from Champréveyres and Monruz date these assemblages to the Oldest Dryas, RPAZ CHb-1c, whereas palynological investigations at Moosbühl tend to place the techno-assemblage from that site either to RPAZ CHb-1c or CHb-2 (Bullinger et al., 1997). 
Techno-assemblage $\boldsymbol{E}$. This assemblage is characterized by industries containing angle-backed points, shouldered points and few curve-backed points, associated with backed bladelets. Industries of this type are recorded in cave sites such as Kohlerhöhle (Sedlmeier 1993, 1998, Fig. 12) and Kastelhöhle Nord (Schweizer et al., 1959) as well as in open-air sites like Winznau-Köpfli (Zürcher, 1969), Kottwil-Hubelweid (Nielsen, 1999) and possibly Einsiedeln-Langrüti, a site located at the edge of Lake Sihlsee at an altitude of nearly $900 \mathrm{~m}$ in the Alps (Leuzinger-Piccand, 1996). In the sites where bone is preserved, the fauna comprises horse and reindeer besides various other cold adapted species. The two important cave sites Kohlerhöhle and Kastelhöhle have also produced single- and double beveled antler points, but since the layers containing the Magdalenian occupation horizons are quite thick, it is impossible to determine with what stone industry these elements were precisely associated.

\section{The reference sites Monruz and Champréveyres}

At the present state of research, only the Magdalenian and Azilian industries of Monruz and Champréveyres can be considered being accurately integrated in the palaeobotanical reference sequence established for the Swiss Plateau and may therefore serve as reference assemblages (Fig. 5). The occupation horizons were interstratified within well developed sedimentary sequences containing pollen, macrorests, insects, mollusks, etc. (Moulin, 1991; Leesch, 1997; Coope and Elias, 2000; Leesch et al., 2004; Bullinger et al., 2006). Moreover, the Magdalenian and Azilian layers were rich in faunal and botanical remains. Of particular interest are the abundant charcoal fragments and diverse other charred plant macrofossils that were extracted from the combustion residues preserved in the hearths (Fig. 13 and 14). The anthracological determinations show that, besides low quantities of Betula, more than $96 \%$ of the charcoal fragments analyzed from the Magdalenian hearths is Salix (probably the low to the ground growing species Salix retusa), whereas the wood spectra from the Azilian hearths are more diverse, including Juniperus as the dominant species, together with Betula and Salix, but neither Pinus nor Populus. In terms of relative chronology, the Magdalenian occupation horizons are therefore correlated with the regional PAZ CHb-1c, before the onset of the expansion of Juniperus on the Swiss Plateau. Since Juniperus develops only at the beginning of the climatic warming correlated with Greenland Interstadial GI-1e, the Azilian horizons fall either within the regional PAZ CHb-2 or at the beginning of the following PAZ $\mathrm{CHb}-3$ in which juniper is still well represented. The radiocarbon dates obtained from charcoal and bone material date the Magdalenian occupations to $c$. 13000 BP (c. 15500 cal BP), confirming their relative chronological position within the palaeobotanical frame. The dates obtained on charcoal from the Azilian layers of Monruz and Champréveyres situate these occupations to c. 12300 BP (c. 14400 cal BP) either still within CHb-2 dominated by Juniperus or within the succeeding pollen assemblage zone $\mathrm{CHb}-3 \mathrm{a}$.

The Magdalenian occupation horizons from the other sites in Switzerland having not produced any botanical remains, it is impossible to correlate the techno-assemblages $\mathrm{B}, \mathrm{C}$ and $\mathrm{E}$ with one of the defined regional pollen assemblage zones. The chronological position of these assemblages can therefore be inferred only from the radiocarbon dates. However, this type of correlation based solely on radiocarbon ages remains unsatisfying because the accuracy of the radiocarbon dates cannot be verified by the botanical data (Leesch, 2000).

\section{New AMS radiocarbon determinations from different Magdalenian sites}

In the course of the last two decades, more than 40 AMS radiocarbon measurements were performed on bone/antler material from different Magdalenian sites (Leesch and Müller 2012) in addition to the 22 existing ones performed on charcoal from Champréveyres and Monruz (Leesch, 1997; Bullinger et al., 2006). These measurements were undertaken in order to verify the results obtained in earlier years by the conventional method and to refine the chronological position of the various assemblages (Fig. 15). However, the bones collected from caves and rockshelters do not usually result from a single occupation but from a succession of an unknown number of stays. Moreover, due to the rather approximate excavation techniques prior to the 1970s the finds could usually not be attributed to one single or thin occupation layer. Therefore, these remains do not fulfill the required archaeological evaluation criteria (Pettitt et al. 2003) and are unsuitable for reliable correlation of the obtained dates with specific industries. In most cases the results merely give a rough indication as to the date of certain occupation episodes.

The AMS dates were performed on bone samples originating from eight caves and three open-air sites : Kesslerloch (16 dates), Hollenberg-Höhle 3 (4 dates), Büttenloch (4 dates), Birseck-Ermitage (1 date), Kohlerhöhle (5 dates), Käsloch (3 dates), Rislisberghöhle (5 dates), Kastelhöhle Nord (3 dates), Moosbühl (1 date), Champréveyres ( 2 dates) and Monruz ( 1 date). The three new dates obtained for Monruz and Champréveyres were undertaken in order to compare the results gained from bone material with those previously obtained on charcoal and to compare them with the dates obtained on bones from the Magdalenian sites in the Paris Basin (Bodu et al., 2009). The results of the measurements are presented in Fig. 15, together with the 
calibrated dates expressed in cal $\mathrm{BC}$ with a confidence interval of $94.5 \%$. However, in the text section only the $\mathrm{BP}$ dates are used for better readability.

On the whole, the dates obtained by using AMS technique are older by several hundred years than those previously obtained by the conventional method. They tend to demonstrate that most Magdalenian sites pre-date the Greenland Interstadial 1e. The oldest date, $16205 \pm 55 \mathrm{BP}$, stems from a metacarpus of reindeer from Kohlerhöhle, a cave excavated between 1934 and 1938 that yielded an upper layer up to $60 \mathrm{~cm}$ thick, containing a very rich Magdalenian assemblage, and a lower layer containing only few objects that cannot be assigned to a specific culture but associated with bones of mammoth, cave bear and lion (Lüdin, 1963; Sedlmeier, 1993). The cave being situated some $50 \mathrm{~km}$ north of the maximum extension of the ice during the LGM, it appears that human groups were occupying this area at an early stage of the Magdalenian expansion. Moreover, this date is close to the oldest date obtained for the large open-air site Munzingen (Pasda, 1994, 1998), situated in the Rhine valley some $50 \mathrm{~km}$ north of the Kohlerhöhle. Caves that were occupied during the middle Magdalenian are also known in France, north of the Jura mountain, for example in Arlay (Cupillard and Welté, 2006; Leesch et al., in press). A Magdalenian occupation as early as $16000 \mathrm{BP}$ does therefore seem possible, especially since this region had already been populated during the Badegoulian, at around 19000 BP. However, Kohlerhöhle having also produced four younger dates $(12790 \pm 45 \mathrm{BP}, 12465 \pm 40 \mathrm{BP}, 12460 \pm 45 \mathrm{BP}, 11525 \pm 60 \mathrm{BP})$, it can however not be ruled out that this old date represents a statistical outlier. Taking into account the thickness of the archaeological layer, it is also likely that the assemblage contains a mixture of elements from different technoassemblages; the presence of some angle-backed points, curve-backed points and backed bladelets (Fig. 13) points to late Magdalenian and Azilian occupation phases.

The oldest date from Kesslerloch, around $15000 \mathrm{BP}$, may be not reliable because the mammoth bone on which the determination was performed had bad collagen preservation (Napierala, 2008, p. 16). Four other dates are situated around 14000 BP. They have been obtained on bones from mammoth, rhinoceros, and horse and from a shed reindeer antler bearing debitage marks. These dates could fit with some objects characteristic of the middle Magdalenian, such as the baguettes demi-rondes à décor de tubérosités and the sagaies of the Lussac-Angles type (Fig. 9) which show good parallels with similar objects dated to approximately the same period in southern France. The other dates indicate that the site was probably occupied repeatedly until $12500 \mathrm{BP}$, before the onset of the climatic warming correlated with the expansion of juniper. These dates confirm the palynological dating that places the occupations in the Oldest Dryas (Ammann et al., 1988). Two dates also suggest an Azilian occupation: one stems from a skull bone of a $\operatorname{dog}(12225 \pm 45 \mathrm{BP})$, the other one from a calcaneus of a red deer $(12335 \pm 45 \mathrm{BP})$.

The cave of Käsloch has produced a relatively old date of $13760 \pm 45$ BP obtained from a horse tooth, in addition of two younger dates around 12500 BP. This site was excavated in 1905 and contained a rich Magdalenian assemblage (more than 200 cores) included in a layer $50 \mathrm{~cm}$ thick (Zuberbühler Koch, 2002). The lithic industry suggests a mixture of artefacts belonging to techno-assemblage $\mathrm{D}-\mathrm{a}$ and techno-assemblage $\mathrm{E}$.

The five new dates obtained for Rislisberghöhle span from $13000 \pm 50 \mathrm{BP}$ to $10770 \pm 45 \mathrm{BP}$. This small cave excavated between 1971 and 1973 has been published only partially (Barr, 1977; Stampfli, 1983). The Magdalenian layer was up to $60 \mathrm{~cm}$ thick and contained a rich assemblage comprising 129 cores, more than 700 backed bladelets and close to 50 bone needles. The site is also famous for having produced the engraving of an ibex on a flat bone. Three dates obtained from bones of ibex, deer and reindeer, respectively, fall within the Oldest Dryas, the one performed on reindeer being the oldest one. Two younger dates obtained from horse teeth would rather be compatible with an Azilian occupation. A brief utilization of the cave during the Azilian seems to be also demonstrated by several curve-backed points.

For Kastelhöhle Nord, in addition to three dates obtained for the middle, Badegoulian, layer (see above), three dates were also obtained for the upper, Magdalenian layer. This layer of $25 \mathrm{~cm}$ thickness contained a rich Magdalenian assemblage (116 cores,) probably belonging to different techno-assemblages, most likely to D-a and E (Schweizer et al., 1959; Pflugi and Sedlmeier, 1988). One bone from Bos/Bison has produced a date of $13435 \pm 50 \mathrm{BP}$ and is clearly situated within the Oldest Dryas. The two other dates obtained on bones from reindeer are respectively dated to $12395 \pm 45$ and $12215 \pm 45 \mathrm{BP}$. The latter ones are similar to those obtained for the Azilian occupations at Monruz and Champréveyres and, therefore, appear to be somewhat too young for a late Magdalenian occupation.

The four new AMS dates obtained on bones from Büttenloch suggest that this cave was occupied not only during the Magdalenian but maybe also during the Azilian. During the excavation that took place in 1918/1919 a $50 \mathrm{~cm}$ 
thick layer had been subdivided into a lower unit (layer A) and an upper unit (layer B), both attributed to the Magdalenian (Sarasin and Stehlin, 1924; Sedlmeier, 1989; Schibler and Sedlmeier, 1993), but based only on a very small assemblage that cannot be assigned to a specific techno-assemblage. The bones from arctic hare attributed to the lower layer have produced two AMS dates around. $12800 \mathrm{BP}(12870 \pm 80 \mathrm{BP}, 12750 \pm 80 \mathrm{BP})$, whereas the samples of ptarmigan attributed to the upper layer produced two dates around $12200 \mathrm{BP}(12170 \pm$ $80 \mathrm{BP}, 12180 \pm 90 \mathrm{BP}$ ). The latter results would better correspond to an occupation by Azilian groups; however, none of the few associated artefacts with this layer can be accurately attributed to this culture.

Four consistent dates, situated between $13114 \pm 71 \mathrm{BP}$ and $12798 \pm 70 \mathrm{BP}$ have been obtained for the cave Hollenberg-Höhle 3. This small cavity excavated in 1950, contained a small assemblage, possibly stemming from only one occupation (Sedlmeier, 1982; Müller and Leesch, 2011). It is famous for having produced a complete rondelle perforée made from jet (Álvarez Fernández, 2005) and another one made from a thin bone plate, together with 34 mollusk shells. The industry, although not numerous, can be attributed to technoassemblage D-a, while the radiocarbon dates, indicate a position within the Oldest Dryas.

Three dates obtained from horse bones sampled at Champréveyres and Monruz (12815 $\pm 65 \mathrm{BP}, 12805 \pm 75 \mathrm{BP}$, $13055 \pm 60 \mathrm{BP})$ are in good agreement with the AMS dates obtained in earlier years from wood charcoal (Leesch, 1997; Bullinger et al., 2006). They confirm the dating of both sites to $c$. 13000 BP (c. 15500 cal BP). They also demonstrate that, when sampling is operated under good stratigraphic control, there is no significant difference between dates obtained from bone material and dates from plant remains.

The new AMS measurements performed at Birseck-Ermitage and Moosbühl do not help to better date the assemblages from these sites. Birseck-Ermitage, a vast rock shelter that has been excavated from 1910-1914 (Sarasin, 1918; Sedlmeier, 1998), has produced a characteristic assemblage comprising scalene triangles and baguettes demi-rondes attributed to techno-assemblage B (Fig. 8), whose chronological position is still debated. The new AMS measurement performed on a reindeer bone has produced a date of $11900 \pm 55 \mathrm{BP}$. This result is similar to two dates obtained in earlier years by the conventional method. However, we consider that these dates do not correspond to the effective age of this assemblage, since it would signify that Magdalenian groups would have coexisted in the same area with Azilian groups, the former hunting reindeer, the latter hunting red deer. Similarly, a new measurement performed on a worked reindeer antler from Moosbühl has produced a date of $7590 \pm 40 \mathrm{BP}$ which is doubtless an outlier and therefore does not help to determine the absolute age of the particular assemblage designated as techno-assemblage D-b (Fig. 11). These too young dates remind us that obviously erroneous dates, i.e., results that are too young by several thousand years, are easily identifiable as such, but that dates that are "wrong" by only 500 or 1000 years are not recognizable as incorrect because they fall within a plausible time span.

\section{A well established Magdalenian population before GI-1e}

The spatial, temporal and causal aspects of the re-colonization of the area of Switzerland after the Last Glacial Maximum can be reconstructed at present in the following details. As proven by two sites, the area north of the Jura Mountain was populated already during at least the final phase of the LGM, so that for the re-colonization of the Swiss Plateau, one must not a priori invoke an "immigration" of people from distant refugia. The melting of the glaciers is described as a rapid collapse rather than a slow melt down (Ivy-Ochs et al., 2004), however, the meaning of "rapid" has to be put in a geologist's perspective. Between the onset of the melt down and the time the glaciers had completely liberated the Swiss Plateau lie probably at least some 2000 years. This means that the areas towards the farthest extent of the glaciers could be re-colonized much earlier than those closer towards the Alps. However, this succession cannot be retraced by the archaeological record since there are too few sites known today on the Swiss Plateau. At the same time, it might not be complete coincidence that the earliest date for a Magdalenian site in Switzerland south of the Jura Mountain comes from Kesslerloch close to Schaffhausen, lying right at the ice margin during the LGM and must, therefore, have been liberated from ice right after the onset of the ice decay.

We argue here that human colonization of a newly accessible area should be set in relation to the colonization of the landscape by plant and animal communities and not primarily to climatic events. As the plant cover develops, it will eventually be productive enough to sustain large herbivores like reindeer and wild horse. If the snow cover in winter is low enough that these animals can access the vegetation they will be present in the area all year round. As soon as these herbivores are present in an area one can assume that human groups are capable of surviving as well. As demonstrated by the radiocarbon dates, most sites fall within the Oldest Dryas, essentially the stage that is correlated with GS-2a, a phase that was probably even colder than the preceding phase GS-2b (Schoeneich, 2003). Obviously, from at least 17000 cal BP the ice-free zones at low altitudes were sufficiently 
re-colonized by vegetation to allow large animals to sustain themselves. Though the Magdalenian occupation was certainly not as dense as in the core area of southern France and Cantabria, there is no proof for a substantial time lag between occupation of the "classical" region and more "peripheral" zones.

In all assemblages known at the present state of research, local and regional flint sources are dominant. The distance of procurement generally does not exceed $40 \mathrm{~km}$. None of the assemblages, not even the Badegoulian assemblage of Kastelhöhle Nord, is composed of raw materials originating from long distances that would show links to a territory from which "pioneers" would have emigrated. The distance to the raw material sources is only longer when the sites are situated in a "flint-less" area such as the central Swiss Plateau, or when they are located in a region offering only low quality raw material not well adapted to the production of backed bladelets. In this case, the distances of transport may be up to $120 \mathrm{~km}$; however, they do not indicate a favored direction as would be the case for pioneer settlements still attached to their home-region. In all the cases, the exploited raw materials show multidirectional provenance (Affolter, 2002, pp. 171-180), proving a well established population living in an environment most familiar to them. This behavior also demonstrates that occurrence or absence of flint in a region is of minor or of no importance at all. High mobility and/or a well functioning network with neighboring groups allowed colonization of all territories where vegetation was sufficiently developed to allow large herbivorous animals to graze and where the topography of the landscape permitted to set up successful hunting strategies.

Reindeer and wild horse are the main big game species in all sites, whereas bison is only attested in small numbers. Usually the faunal assemblages are dominated by either one of the two species, reindeer or horse, which might be due to seasonal or geographic/topographic factors. However, when bone preservation is good and when excavation techniques include wet-sieving of the sediments, the diversity of the faunal assemblages is high and contains also animals of small and medium size such as ibex, marmot, alpine hare, arctic fox, ground squirrel and pika, together with various birds and fishes. Seasonal determinations are currently investigated for all sites that have produced animal remains in order to reconstruct the dynamics of land use by the Magdalenian groups throughout the seasonal cycle. While this work is still in progress, it has already become clear that Switzerland was not only occupied during the "warm" (spring-autumn) season but all year round. High residential mobility characterizes the behavior of the groups during the warm season, especially when horses were hunted. As could be demonstrated from the archaeozoological study of the open-air sites Champréveyres and Monruz, it was indeed more efficient to move the camp to the kill site of the horses than to carry the carcasses several kilometers back to a "base camp" (Müller et al., 2006). Thus, the kill-butchering site was transformed into a temporary campsite where the whole group stayed for a few weeks according to the number of horses that were killed (usually one to a maximum of three animals), before moving to another kill-site.

No significant changes in subsistence behavior can be observed between the Middle and the Upper Magdalenian. As far as can be reconstructed from the provenance of the flint materials that were used, the territories did not change notably (Affolter, 2009). It seems that we are dealing with well established regional groups maintaining multidirectional contacts, however circulating along certain axes determined by topographical features and river systems (Cattin et al., 2009). As shown by the mollusks and by the feminine figurines that were found in the cave of Petersfels (southwest Germany) and in Monruz, the Magdalenian groups living at the Jura foothill had particularly strong ties to the upper Danube basin, while those living north of the Jura chain, in the region of the Birse river, were more specifically oriented towards the Rhine valley. Most of the latter sites have indeed produced fossil mollusks originating from the Mainz basin (Sedlmeier, 1988; Eriksen, 2002; Álvarez Fernández, 2005) and/or from the Paris basin, while only one of them (Kohlerhöhle) has produced a shell from the upper Danube basin. The shells from the upper Danube basin are distributed over a distance of $c .250 \mathrm{~km}$ and may indicate the extension of the territory inhabited by members of the same group. A few Mediterranean shells, and even amber from the Baltic Sea (Beck, in Schwab, 1985; Beck, 1997), testify however for the existence of an even farther reaching network of social relationships that permitted the diffusion of these exotic elements over more than $500 \mathrm{~km}$.

\section{Acknowledgments}

The authors would like to thank Lawrence Straus for initiating the session on the Magdalenian at the INQUA Congress in Bern. We are grateful to Jörg Schibler and Jürg Sedlmeier for providing unpublished radiocarbon dates from Büttenloch, Kohlerhöhle and Käsloch. Thanks are also due to Reto Marti (director of the cantonal survey of Basel-Landschaft) and Pierre Harb (director of the cantonal survey of Solothurn) for financing the radiocarbon measurements of the caves in the canton they are in charge of. For the dating of the Moosbühl sample we are grateful to Marcel Güntert, former Director of the Naturhistorisches Museum Bern. We are also indebted to Boris Valentin for having initiated the dating of three bone samples from Monruz and 
Champréveyres in the framework of a research program that he is directing (PCR, "Paléoltihique final et Mésolithique dans le Bassin parisien et ses marges") and for the financial support for realizing the measurements. This contribution is part of a project funded by the Swiss National Science Foundation (project no. 124457).

\section{References}

Affolter, J., 2002. Provenance des silex préhistoriques du Jura et des régions limitrophes. Service et Musée cantonal d'archéologie, Neuchâtel.

Affolter, J., 2009. La grotte de Bange (Allèves, Haute-Savoie), in: Pion, G., Mevel, L. (Eds.), La fin du Paléolithique supérieur dans les Alpes françaises et le Jura méridional. Approches culturelles et environnementales. Projet collectif de recherche sous la direction de Gilbert Pion. Société préhistorique française, mémoire L, Paris, pp. 173-181.

Alvarez Fernández, E., 2005. "Eloignés mais pas isolés": la parure hors de la "frontière française" pendant le Magdalénien, in: Dujardin, V. (Ed.), Industrie osseuse et parures du Solutréen au Magdalénien en Europe. Table ronde sur le Paléolithique supérieur récent, Angoulême, 20-23 mars 2003. Société préhistorique française, Mémoire 39, Paris, pp. 25-38.

Ammann, B., 1989. Late-Quaternary palynology at Lobsigensee: regional vegetation history and local development. Dissertationes Botanicae, 137, Cramer, Berlin.

Ammann, B., Bandi, H.-G., Buser, M., Chaix, L., Joos, M., Mäglin, T., Riesen, T., Schibler, J., Schoch, W.H., Sedlmeier, J., Stampfli, H.R., Wohlfarth-Meyer, B., 1988. Neue Untersuchungen am Kesslerloch bei Thayngen/SH. Sondierbohrungen im östlichen Vorplatzbereich und ihre naturwissenschaftlich-archäologische Auswertung. Schweizerische Gesellschaft für Ur- und Frühgeschichte, Basel.

Ammann, B., Gaillard, M.-J., Lotter, A.F., 1996. Switzerland, in: Berglund, B.E., Birks, H.J.B., RalskaJasiewiczowa, M., Wright, H.E. (Eds.), Palaeoecological events during the last 15000 years. Regional syntheses of palaeoecological studies of lakes and mires in Europe. John Wiley and Sons, Chichester, New York, pp. 647 666.

Ammann, B., Lotter, A.F., 1989. Late-Glacial radiocarbon and palynostratigraphy on the Swiss Plateau. Boreas $18,109-126$.

Barr, J.H., 1977. Die Rislisberghöhle, ein neuer Magdalénien-Fundplatz im Schweizer Jura. Archäologisches Korrespondenzblatt 7, 85-87.

Beck, C., 1997. Détermination de la provenance des résines fossiles par l'analyse spectrale en infrarouge, in: Leesch, D. (Ed.), Hauterive-Champréveyres, 10. Un campement magdalénien au bord du lac de Neuchâtel: cadre chronologique et culturel, mobilier et structures, analyse spatial (secteur 1). Musée cantonal d'archéologie, Neuchâtel, pp. 105-107.

Bini, A., Buoncristiani, F., Couterrand, S., Ellwanger, D., Fleber, M., Florineth, D., Graf, H.R., Keller, O., Kelly, M., Schlüchter, C., Schoeneich, P., 2009. La Suisse durant le denier maximum glaciaire (LGM). 1:500000. Federal Office of Topography swisstopo, Switzerland.

Björck, S., Walker, M.J.C., Cwynar, L.C., Johnsen, S., Knudsen, K.-L., Lowe, J.J., Wohlfarth, B., 1998. An event stratigraphy for the Last Termination in the North Atlantic region based on the Greenland ice-core record: a proposal by the INTIMATE group. Journal of Quaternary Science 13, 283-292.

Bodu, P., Debout, G., Dumarçay, G., Leesch, D., Valentin, B., 2009. Révision de la chronologie magdalénienne dans le Bassin parisien et alentours: nouveaux résultats, in: Valentin, B. (Ed.), Paléolithique final et Mésolithique dans le Bassin parisien et ses marges. Habitats, sociétés et environnements. Projet collectif de recherche. Programmes P7, P8 et P10. Rapport d'activités pour 2009, pp. 91-99.

Braillard, L., Menoud, S., Mauvilly, M., Boisaubert, J.-L., Baeriwyl, J.-M., 2003. Préalpes et chasseurscueilleurs en terres fribourgeoises. Cahiers d'archéologie fribourgeoise 5, 42-69. 
Bullinger, J., Huber, R., 2010. Au temps des chasseurs-cueilleurs. Archéologie suisse 33, 15-21.

Bullinger, J., Lämmli, M., Leuzinger-Piccand, C., 1997. Le site magdalénien de plein air de Moosbühl: nouveaux éléments de datation et essai d'interprétation des données spatiales. Annuaire de la Société suisse de préhistoire et d'archéologie 80, 7-26.

Bullinger, J., Leesch, D., Plumettaz, N., 2006. Le site magdalénien de Monruz, 1. Premiers éléments pour l'analyse d'un habitat de plein air, Service et musée cantonal d'archéologie de Neuchâtel, Hauterive.

Burg, A. von, 1994. Die Silexfundkomplexe des Oberaargaus (Kt. Bern). Universität Bern.

Burga, C.A., Perret, R., 1998. Vegetation and climate history in Switzerland during the later Pleistocene and Holocene. Ott Verlag, Thun.

Cattin, M.-I., Affolter, J., Thew, N., 2009. Provenance de diverses matières premières: un indice pour définir circulations et territoires au Magdalénien supérieur en Suisse, in: Djindjian, F., Kozlowski, J., Bicho, N. (Eds.), Le concept de territoires dans le Paléolithique supérieur européen. Actes du XVe Congrès mondial UISPP (Lisbonne, 4-9 septembre 2006), Archaeopress, Oxford, pp. 157-165.

Coope, R., Elias, S., 2000. The environment of Upper Palaeolithic (Magdalenian and Azilian) hunters at Hauteirve-Champréveyres, Neuchâtel, Switzerland, interpreted from coleopteran remains. Journal of Quaternary Science 15, 157-175.

Coope, R., Lemdahl, G., 2009. Insect analyses, in: Thew, N., Hadorn, P., Coope, R. (Eds.), Hauterive/RougesTerres. Reconstruction of Upper Palaeolithic and Early Mesolithic environments. Office et Musée cantonal d'archéologie, Neuchâtel, pp. 125-159.

Crotti, P., 1993. L'Epipaléolithique et le Mésolithique en Suisse: les derniers chasseurs, in: Schweizerische Gesellschaft für Ur-und Frühgeschichte. (Ed.), La Suisse du Paléolithique à l'aube du Moyen-Age. I. Paléolithique et Mésolithique, Bâle, pp. 203-241.

Crotti, P., 2008. Le peuplement paléolithique et mésolithique de la Suisse: la question de l'utilisation des étages montagnards dans les Alpes. Geographica Helvetica 63, 167-175.

Cupillard, C., Welté, A.-C., 2006. Le Magdalénien de la grotte "Grappin" à Arlay (Jura, France): nouveaux regards. L'Anthropologie 110, 624-683.

Ehlers, J., Gibbard, P.L., 2004. Quaternary glaciations: Extent and chronology, part I: Europe. Elsevier, London.

Elias, S., Wilkinson, B., 1983. Lateglacial insect fossil assemblages from Losigensee (Swiss Plateau). Studies in Late Quaternary of Lobsigensee, 3. Revue de Paléobiologie 2, 189-204.

Eriksen, B.V., 1991. Change and continuity in a prehistoric hunter-gatherer society: a study of cultural adaptation in late glacial-early postglacial southwestern Germany. Archaeologica Venatoria, Tübingen.

Eriksen, B.V., 2002. Fossil mollusks and exotic raw materials in Late Glacial and early Postglacial find contexts. A complement to lithic studies, in: Fisher, L., Eriksen, B.V. (Eds.), Lithic raw material economy in Late Glacial and early Postglacial western Europe. Archaeopress, Oxford, pp. 27-52.

Gaillard, M.-J., 1984. Etude palynologique de l'évolution tardi- et postglaciaire de la végétation du Moyen-Pays Romand (Suisse). Dissertationes botanicae, J. Cramer, Vaduz.

Gaillard, M.-J., 2004. Datation palynologique et milieu végétal des niveaux magdaléniens et de l'horizon azilien, in: Leesch, D., Cattin, M.-I., Müller, W. (Eds.), Hauterive-Champréveyres et Neuchâtel-Monruz. Témoins d'implantations magdaléniennes et aziliennes sur la rive nord du lac de Neuchâtel. Service et musée cantonal d'archéologie de Neuchâtel, Hauterive, pp. 13-19.

Gaillard, M.-J., Lemdahl, G., 1994. Lateglacial insect assemblages from Grand-Marais, south-western Switzerland. Climatic implications and comparisons with pollen and plant macrofossil data, in: Lotter, A.F., 
Ammann, B. (Eds.), Festschrift Gerhard Lang. Beiträge zur Systematik und Evolution, Floristik und Geobotanik, Vegetationsgeschichte und Paläoökologie. Cramer, Berlin, Stuttgart, pp. 287-308.

Hadorn, P., Thew, N., Coope, R., Lemdahl, G., Hajdas, I., Bonani, G., 2002. A Late-Glacial and Early Holocene environment and climate history for the Neuchâtel region $(\mathrm{CH})$, in: Richard, H., Vignot, A. (Eds.), Equilibres et ruptures dans les écosystèmes durant les 20 derniers millénaires en Europe de l'Ouest. Actes du colloque international de Besançon, 18-22 septembre 2000. Presses Universitaires de Franche-Comté, Besançon, pp. 7590.

Hajdas, I., Bonani, G., Furrer, H., Mäder, A., Schoch, W., 2007. Radiocarbon chronology of the mammoth site at Niederweningen, Switzerland: Results from dating bones, teeth, wood and peat. Quaternary International 164$165,98-105$.

Hajdas, I., Bonani, G., 2009. Radiocarbon dating and chronology of the Late-Glacial and Early Holocene sequence, in: Thew, N., Hadorn, P., Coope, R. (Eds.), Hauterive/Rouges-Terres. Reconstruction of Upper Palaeolithic and Early Mesolithic environments. Office et Musée cantonal d'archéologie, Neuchâtel, pp. 81-93.

Heiri, O., Millet, L., 2005. Reconstruction of Late Glacial summer temperatures from chironomid assemblages in Lac Lautrey (Jura, France). Journal of Quaternary Science 20, 33-44.

Höneisen, M., 1993. Technologie du bois de cervidé, de l'os et de l'ivoire. In: Höneisen, M., Leesch, D., Le Tenorer J.-M. Le Paléolithique supérieur récent, in: Schweizerische Gesellschaft für Ur-und, F. (Ed.), La Suisse du Paléolithique à l'aube du Moyen-Age. I. Paléolithique et Mésolithique, Bâle, pp. 173-181.

Höneisen, M., Leesch, D., Le Tensorer, J.-M., 1993. Le Paléolithique supérieur récent, in: Schweizerische Gesellschaft für Ur-und Frühgeschichte (Ed.), La Suisse du Paléolithique à l'aube du Moyen-Age. I. Paléolithique et Mésolithique, Bâle, pp. 153-201.

Housley, R.A., Gamble, C.S., Street, M., Pettitt, P., 1997. Radiocarbon evidence for the Lateglacial human recolonisation of northern Europe. Proceedeings of the Prehistoric Society 63, 25-54.

Ivy-Ochs, S., Kerschner, H., Reuther, A., Preusser, F., Heine, K., Maisch, M., Kubik, P.W., Schlüchter, C., 2008. Chronology of the last glacial cycle in the European Alps. Journal of Quaternary Science 23, 559-573.

Ivy-Ochs, S., Schäfer, J., Kubik, P.W., Synal, H.-A., Schlüchter, C., 2004. The timing of deglaciation on the northern Alpine foreland (Switzerland). Eclogae geologicae Helvetiae 97, 47-55.

Kelly, M., Buoncristiani, J.-F., Schlüchter, C., 2004. A reconstruction of the last glacial maximum (LGM) icesurface geometry in the western Swiss Alps and contiguous Alpine regions in Italy and France. Eclogae geologicae Helvetiae 97, 57-75.

Lang, G., 1985. Swiss lake and mire environments during the last 15000 years. Dissertationes botanicae, J. Cramer, Vaduz.

Le Tensorer, J.-M., 1998. Le Paléolithique en Suisse. Editions Jérôme Millon, Grenoble.

Leesch, D., 1993. Cadre chronologique et faciès industriels, in: Le Tensorer, J.-M., Niffeler, U. (Eds.), La Suisse du Paléolithique à l'aube du Moyen-Age. I. Paléolithique et Mésolithique, Bâle, pp. 153-164.

Leesch, D., 1997. Hauterive-Champréveyres, 10. Un campement magdalénien au bord du lac de Neuchâtel. Cadre chronologique et culturel, mobilier et structures, analyse spatiale (secteur 1). Musée cantonal d'archéologie, Neuchâtel.

Leesch, D., 2000. Le tardiglaciaire en Suisse: corrélation des données paléoenvironnementales et archéologiques, in: Valentin, B., Bodu, P., Christensen, M. (Eds.), L'Europe centrale et septentrionale au Tardiglaciaire. Confrontation des modèles régionaux de peuplement. Actes de la Table-ronde internationale de Nemours (14-16 mai 1997). Association pour la promotion de la recherche archéologique en Ile-de-France, Nemours, pp. $217-$ 221. 
Leesch, D., Bullinger, J., Cupillard, C., in press. Le peuplement de l'arc jurassien au Paléolithique supérieur, in: Richard, A., Schifferdecker, F., Mazimann, J.-P., (dir.). Le peuplement de l'Arc jurassien de la Préhistoire au Moyen Âge. Actes des deuxièmes journées archéologiques frontalières de l'Arc jurassien, Delle $(\mathrm{F})-\mathrm{Boncourt}$ (CH), 16-18 novembre 2007. Besançon. Presses Universitaires de Franche-Comté et Porrentruy, Office de la Culture et Société jurassienne d'Émulation.

Leesch, D., Cattin, M.-I., Müller, W., 2004. Hauterive-Champréveyres et Neuchâtel-Monruz. Témoins d'implantations magdaléniennes et aziliennes sur la rive nord du lac de Neuchâtel. Service et musée cantonal d'archéologie de Neuchâtel, Hauterive.

Leesch, D., Müller, W., 2012. Neue Radiokarbondaten an Knochen, Zähnen und Geweih aus einigen Magdalénien-Fundstellen der Schweiz, und ihre Bedeutung für die Stellung des Magdalénien innerhalb des Spätglazials, Annuaire d'Archéologie suisse 95, XX-XX.

Leuzinger-Piccand, C., 1996. Einsiedeln SZ-Langrüti : eine spätmagdalénienzeitliche und mesolithische Freilandstation in den Voralpen : Grabungsbericht und Sammlungsstudie. Annuaire de la Société suisse de préhistoire et d'archéologie 79, 7-26.

Lister, G.S., 1988. A 15000-year isotopic record from Lake Zurich of deglaciation and climatic change in Switzerland. Quaternary Research 29, 129-141.

Lotter, A.F., 1991. Absolute dating of Late-Glacial period in Switzerland using annually laminated sediments. Quaternary Research 35, 321-330.

Lotter, A.F., 1999. Late-glacial and Holocene vegetation history and dynamics as shown by pollen and plant macrofossil analyses in annually laminated sediments from Soppensee, central Switzerland. Vegetation History and Archaeobotany 8, 165-184.

Lotter, A.F., Birks, H.J.B., Eicher, U., Hofmann, W., Schwander, J., Wick, L., 2000. Younger Dryas and Alleröd summer temperatures at Gerzensee (Switzerland) inferred from fossil pollen and cladoceran assemblages. Palaeogeography, Palaeoclimatology, Palaeoecology 159, 349-362.

Lotter, A.F., Ammann, B., Beer, J., Hajdas, I., Sturm, M., 1992a. A step towards an absolute time-scale for the late-glacial : annually laminated sediments from Soppensee (Switzerland), in: Bard, E., Broecker, W.S. (Eds.), The last deglaciation : absolute and radiocarbon chronologies, pp. 45-68.

Lotter, A.F., Eicher, U., Siegenthaler, U., Birks, H.J.B., 1992b. Late-glacial climatic oscillations as recorded in Swiss lake sediments. Journal of Quaternary Science 7, 187-204.

Lowe, J.J., Rasmussen, S.O., Björck, S., Hoek, W.Z., Steffensen, J.P., Walker, M.J.C., Yu, Z.C., the INTIMATE group, 2008. Synchronisation of palaeoenvironmental events in the North Atlantic region during the Last Termination: a revised protocol recommended by the INTIMATE group. Journal of Quaternary Science Reviews $27,6-17$

Lüdin, C., 1963. Die Silexartefakte aus dem Spätmagdalénien der Kohlerhöhle. Annuaire de la Société suisse de préhistoire et d'archéologie 50, 33-42.

Magny, M., Aalsbersberg, G., Bégeot, C., Benoit-Ruffaldi, P., Bossuet, G., Disnar, J.-R., Heiri, O., LaggounDefarge, F., Mazier, F., Millet, L., Peyron, O., Vannière, B., Walter-Simonnet, A.-V., 2006. Environmental and climatic changes in the Jura Mountains (eastern France) during the Lateglacial-Holocene transition: a multiproxy record from Lake Lautrey. Quaternary Science Reviews 25, 414-445.

Magny, M., Thew, N., Hadorn, P., 2003. Late-glacial and early Holocene changes in vegetation and lake-level at Hauterive/Rouges-Terres, Lake Neuchâtel (Switzerland). Journal of Quaternary Science 18, 31-40.

Morel, P., Hug, B., 1996. Découverte d'un crâne tardiglaciaire de rhinocéros laineux Coelodonta Antiquitatis (Blumenbach 1799) dans le lac de Neuchâtel, au large de Vaumarcus (NE). Paléontologie et conservation. Bulletin de la Société neuchâteloise des Sciences naturelles 119, 101-110. 
Moulin, B., 1991. Hauterive-Champréveyres 3. La dynamique sédimentaire et lacustre durant le Tardiglaciaire et le Postglaciaire. Editions du Ruau, Saint-Blaise.

Müller, W., Leesch, D., 2011. Einige Neubestimmungen aus der Magdalénien-Fundstelle Hollenberg-Höhle 3 bei Arlesheim (Basel-Landschaft) und daraus folgende Überlegungen zur Nutzung de Höhle. Annuaire d'Archéologie suisse 94, 7-20.

Müller, W., Leesch, D., Bullinger, J., Cattin, M.-I., Plumettaz, N., 2006. Chasse, habitats et rythme des déplacements: réflexions à partir des campements magdaléniens de Champréveyres et Monruz (Neuchâtel, Suisse). Bulletin de la Société préhistorique française 103, 741-752.

Napierala, H., 2008. Die Tierknochen aus dem Kesslerloch. Neubearbeitung der paläolithischen Fauna. Beiträge zur Schaffhauser Archäologie, 2, Baudepartement des Kantons Schaffhausen, Schaffhausen.

Nielsen, E.H., 1994. Rentierjäger in Reiden. Eine neue Fundstelle der Altsteinzeit im Kanton Luzern. Archéologie suisse 17, 126-133.

Nielsen, E.H., 1999. Das Magdalénien im schweizer Mittelland. Archäologisches Korrespondenzblatt 29, 11-20.

Nielsen, E.H., 2002. The Lateglacial settlement of Central Swiss Plateau, in: Eriksen, B.V., Bratlund, B. (Eds.), Recent studies in the Final Palaeolithic of the European plain. Proceedings of the UISPP Symposium, Stockholm, 14-17 octobre 1999. Jutland Archaeological Society, Højbjerg, pp. 189-201.

Nielsen, E.H., 2009. Paläolithikum und Mesolithikum in der Zentralschweiz. Mensch und Umwelt zwischen 17000 und 5500 v. Chr, Luzern.

Pasda, C., 1994. Das Magdalénien in der Freiburger Bucht. Materialhefte zur Archäologie in BadenWürttemberg, 25, Theiss, Stuttgart.

Pasda, C., 1998. Der Beginn des Magdaléniens in Mitteleuropa. Archäologisches Korrespondenzblatt 28, $175-$ 190.

Pettitt, P.B., Davies, W., Gamble, C.S., Richards M.B., 2003. Palaeolithic radiocarbon chronology: quantifying our confidence beyond two half-lifes. Journal of Archaeological Science 30, 1685-1693.

Pflugi, K., Sedlmeier, J., 1988. Ur- und Frühgeschichte der Gemeinde Himmelried, Himmelried (Kanton Solothurn), Heimatkundliche Beiträge zur 700-Jahr-Feier 1988, pp. 42-57.

Preusser, F., 2004. Towards a chronology of Late Pleistocene in the northern Alpine Foreland. Boreas 33, $195-$ 210.

Reimer, P.J., Baillie, M.G.L., Bard, E., Bayliss, A., Beck, J. W., Blackwell, P. G., Bronk Ramsey, C. Buck, C. E., Burr, G. S., Edwards, R. L., Friedrich, M., Grootes, P. M., Guilderson, T. P., Hajdas, I., Heaton, T. J., Hogg, A. G., Hughen, K. A., Kaiser, K. F., Kromer, B. McCormac, F. G., Manning, S. W., Reimer, R. W., Richards, D. A., Southon, J. R., Talamo, S., Turney, C. S. M., van der Plicht, J., Weyhenmeyer, C. E., 2009. IntCal09 and Marine09 radiocarbon age calibration curves, 0-50,000 years cal BP. Radiocarbon 51, 4, 1111-1150.

Richard, H., Bégeot, C., 2000. Le Tardiglaciaire du massif jurassien: bilan et perspectives de recherches. Quaternaire 11, 145-154.

Ruffaldi, P., 1993. Histoire de la végétation du Jura méridional depuis le retrait du glacier würmien à partir des analyses palynologiques du lac de Cerin (Ain, France). Université de Franche-Comté, p. 254.

Ruffaldi, P., 1996. La fin du Pléniglaciaire dans le Jura méridional à partir des analyses polliniques du lac de Cerin (Ain, France). Cahiers R Académie des sciences de Paris 320, 1117-1123.

Sarasin, F., 1918. Die steinzeitlichen Stationen des Birstales zwischen Basel und Delsberg. Georg \& Co, Bâle, Genève, Lyon. 
Sarasin, F., Stehlin, H.-G., 1924. Die Magdalénien-Station bei Ettingen (Baselland). Denkschrift der schweizerischen naturforschenden Gesellschaft 61.

Schibler, J., Sedlmeier, J., 1993. Die Schneehühner- und Schneehasenknochen aus dem Abri Büttenloch (Ettingen BL). Ein Beitrag zur Kenntnis der Jagdbeutenutzung im Spätmagdalénien. Archäologisches Korrespondenzblatt 23, 15-35.

Schoeneich, P., 2003. Que s'est-il passé pendant la première partie du Tardiglaciaire? Indices d'un changement écologique majeur dès 17-18 000 cal BP. Preistoria Alpina 39, 9-17.

Schoeneich, P., Blant, M., Braillard, L., Coutterand, S., Gamond, J.-F., Ivy-Ochs, S., Leesch, D., Ménard, G., Preusser, F., 2011. The age of the LGM in the Western and northwestern Alps (Switzerland and France). Results from various dating techniques. Poster presented at the XVIII INQUA Congress, Bern, Switzerland, 21-27 July 2011.

Schwab, H., 1985. Gagat und Bernstein auf dem Rentierjägerhalt Moosbühl bei Moosseedorf (Kanton Bern), in: Fellmann, R., Germann, G., Zimmermann, K. (Eds.), Jagen und Sammeln. Festschrift für Hans-Georg Bandi zum 65. Geburtstag, Jahrbuch des Bernischen Historischen Museums, 1983-1984, Bern, pp. 259-266.

Schwander, J., Eicher, U., Ammann, B., 2000. Oxygen isotopes of lake marl at Gerzensee and Leysin (Switzerland), covering the Younger Dryas and two minor oscillations, and their correlation to the GRIP ice core. Palaeohistoria 159, 203-214.

Schweizer, T., Schmid, E., Bay, R., Stampfli, H.R., Forcart, L., Fey, L., 1959. Die "Kastelhöhle" im Kaltbrunnental, Gemeinde Himmelried (Solothurn). Jahrbuch für solothurnische Geschichte 32, 1-88.

Sedlmeier, J., 1982. Die Hollenberg-Höhle 3. Eine Magdalénien-Fundstelle bei Arlesheim, Kanton BaselLandschaft. Habegger, Derendingen-Solothurn.

Sedlmeier, J., 1988. Jungpaläolithischer Molluskenschalen-Schmuck aus nordwestschweizerischen Fundstellen als Nachweis für Fernverbindungen. Archäologisches Korrespondenzblatt 18, 1-6.

Sedlmeier, J., 1989. Jungpaläolithikum und Spätpaläolithikum in der Nordwestschweiz. Ein Beitrag zur regionalen Erforschung des Paläolithikums auf Grund ausgewählter Fundinventare aus Grabungen der Jahre zwischen 1910 und 1956. Universität Bern, p. 228.

Sedlmeier, J., 1998. Paläolithikum und Mesolithikum: Die Zeit der Jäger und Sammler, in: Ewald, J., Tauber, J. (Eds.), Tatort Vergangenheit. Ergebnisse aus der Archäologie heute. Wiese Verlag, Basel, pp. 286-348.

Sedlmeier, J., 1993. Altsteinzeitliche Funde aus der Kohlerhöhle im Laufental. Archäologie der Schweiz 16, 4045.

Sedlmeier, J., 2010. Die jungpaläolithischen Funde aus der mittleren Fundschicht der Kastelhöhle Nord im nordwestschweizerischen Kaltbrunnental (Gemeinde Himmelried SO). Ein Nachweis für die Begehung der Schweiz durch Mensch und Tier kurz nach dem Kältemaximum der letzten Eiszeit. Jahrbuch der Archäologie Schweiz 93, 7-34.

Spycher, H., Sedlmeier, J., 1985. Steinzeitfunde bei Erschwil im Schwarzbubenland. Helvetia Archaeologica 16, 78-80.

Stampfli, H.R., 1983. Rislisberghöhle. Archäologie und Ökologie einer Fundstelle aus dem Spätmagdalénien bei Oensingen im Solothurner Jura. Haupt, Bern, Stuttgart.

Svensson, A., Andersen, K., Bigler, M., Clausen, H.B., Dahl-Jensen, D., Davis, S.M., Johnsen, S.J., Muscheler, R., Rasmussen, S.O., Röthlisberger, R., Steffensen, J.P., Vinther, B.M., 2006. The Greenland Ice Core Chronology 2005, 15-42 ka. Part 2: comparison to other records. Quaternary Science Reviews 25, 3258-3267.

Terberger, T., Street, M., 2002. Hiatus or continuity? New results for the question of pleniglacial settlement in Central Europe. Antiquity 76, 691-698. 
Thew, N., Hadorn, P., Coope, R., 2009. Hauterive/Rouges-Terres. Reconstruction of Upper Palaeolithic and early Mesolithic natural environments. Office et musée cantonal d'archéologie, Neuchâtel.

Verbruggen, F., Heiri, O., Reichart, G.-J., Lotter, A.F., 2010. Chironomid $\delta 180$ as a proxy for past lake water 8180: a Lateglacial record from Rotsee (Switzerland). Quaternary Science Reviews 29, 2271-2279.

Walker, M.J.C., Björck, S., Lowe, J.J., Cwynar, L.C., Johnsen, S., Knudsen, K.-L., Wohlfarth, B., INTIMATE group, 1999. Isotopic "events" in GRIP ice core : a stratotype for the Late Pleistocene. Quaternary Science Reviews 18, 1143-1150.

Wegmüller, S., 1966. über die spät-und postglaziale Vegetationsgeschichte des südwestlichen Jura. Beiträge zur geobotanischen Landesaufnahme der Schweiz 48, 144.

Wehrli, M., Tinner, W., Ammann, B., 2007. 16000 years of vegetation and settlement history from Egelsee (Menzingen, central Switzerland). The Holocene 17, 747-761.

Weniger, G.-C., 1982. Wildbeuter und ihre Umwelt. Ein Beitrag zum Magdalénien Südwestdeutschlands aus ökologischer und ethno-archäologischer Sicht. Archaeologica Venatoria, Tübingen.

Wessels, M., 1998a. Late-Glacial and postglacial sediments in Lake Constance (Germany) and their palaeolimnological implications. Archiv für Hydrobiologie 53, 411-449.

Wessels, M., 1998b. Natural environmental changes indicated by Late Glacial and Holocene sediments from Lake Constance, Germany. Palaeogeography, Palaeoclimatology, Palaeoecology 140, 421-432.

Zuberbühler Koch, K., 2002. Die magdalénienzeitliche Höhlenstation Winznau/Käsloch im Kanton Solothurn. Archäologie und Denkmalpflege im Kanton Solothurn 7, 7-49.

Zürcher, A., 1969. Die Spätjungpaläolithische Freilandstation Winznau-Köpfli. Jahrbuch für solothurnische Geschichte 42, 138-201.

\section{Figure captions}

Fig. 1. The three main topographical entities of Switzerland with the location of some lakes and mires that have produced important Late Glacial sequences.

Fig. 2. Switzerland during the Last Glacial Maximum: Only a small area in the northwestern part of the country was left ice-free. The caves Kastelhöhle Nord and Y-Höhle dated to 23000 cal BP are indicated.

Fig. 3. Kastelhöhle Nord (middle archaeological layer): lithic industry assigned to the Badegoulian (from Sedlmeier, 2010).

Fig. 4. Reindeer metatarsal with cut marks from the cave Y-Höhle (photo W. Müller).

Fig. 5. Correlation between the Greenland Ice core chronology, the Regional Pollen Assemblage Zones and the reference sites Monruz and Champréveyres.

Fig. 6. Skull of a woolly rhinoceros (Coelodonta antiquitatis) found in Lake Neuchâtel, dated to $13980 \pm 140 \mathrm{BP}$ (photo Y. André, Office et Musée cantonal d'archéologie, Neuchâtel).

Fig. 7. Location of the Magdalenian sites in Switzerland: only the names of some major sites are indicated (points $=$ caves/rockshelters, triangles $=$ open-air sites).

Fig. 8. Techno-assemblage B, Birseck-Ermitage (from Sedmeier, 1998).

Fig. 9. Techno- assemblage C, Kesslerloch (from Höneisen, 1993). 
Fig. 10. Techno-assemblage D-a, Hauterive-Champréveyres (from Leesch, 1997).

Fig. 11. Techno-assemblage D-b, Moosbühl (from Bullinger et al., 1997; Schwab, 1985).

Fig. 12. Techno-assemblage E, Kohlerhöhle (from Sedlmeier, 1998).

Fig. 13. Hearth from the open-air site Monruz (photo Y. André, Office et Musée cantonal d'archéologie, Neuchâtel).

Fig. 14. Charred seeds from bladder campion (Silene vulgaris) extracted from the combustion residues of the Magdalenian hearths of Monruz: (photo G. Haldimann, Office et Musée cantonal d'archéologie, Neuchâtel).

Fig. 15. AMS-radiocarbon measurements performed on bone, antler, and teeth from Magdalenian sites in Switzerland. The ${ }^{14} \mathrm{C}$ dates are calibrated with the program OxCal v3.10 Bronk Ramsey (2005), using the Intcal09 curve (Reimer et al., 2009); $2 \sigma$ confidence interval, 95,4\% . 


\section{Figure 1}

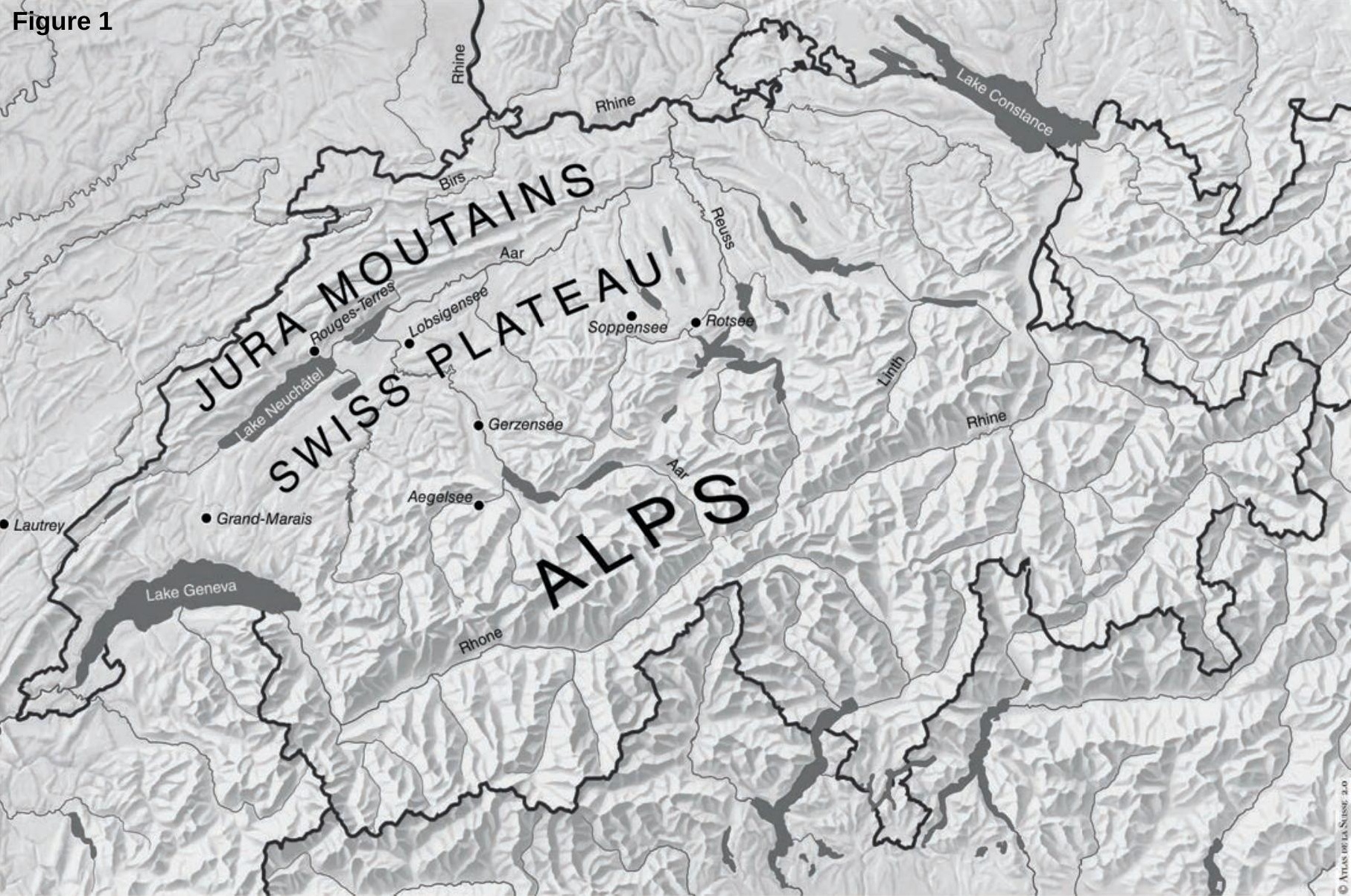




\section{Figure 2}

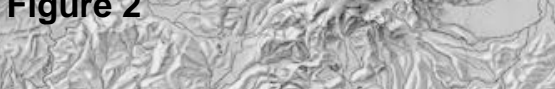
250 20 (1)
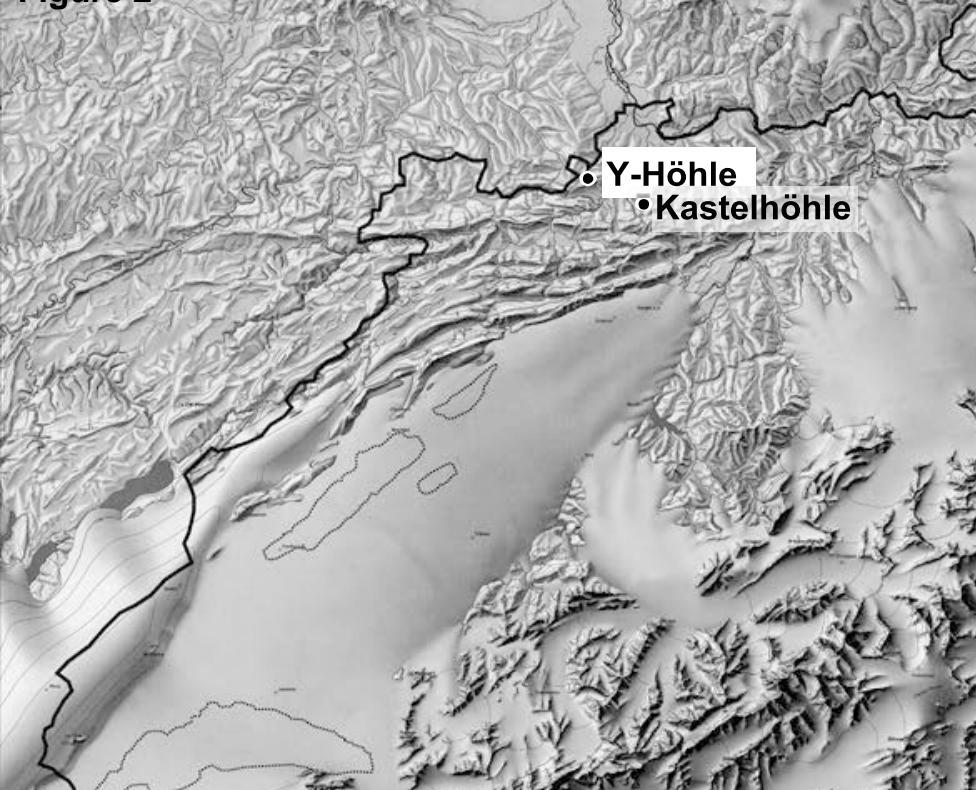

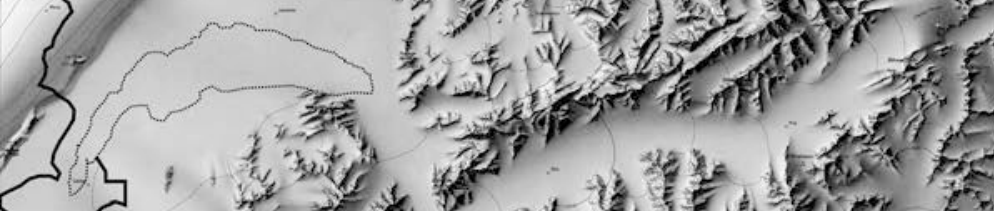
2intor

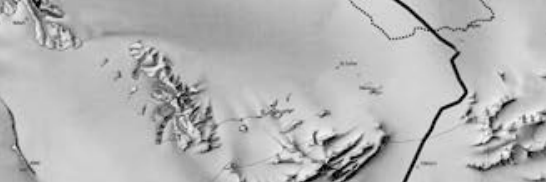

ind Q9.

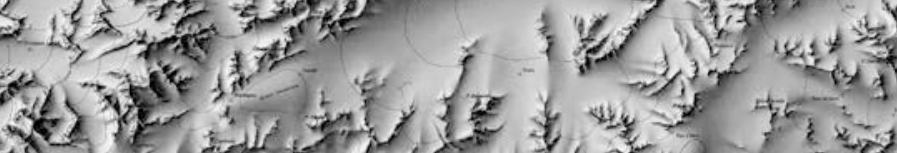

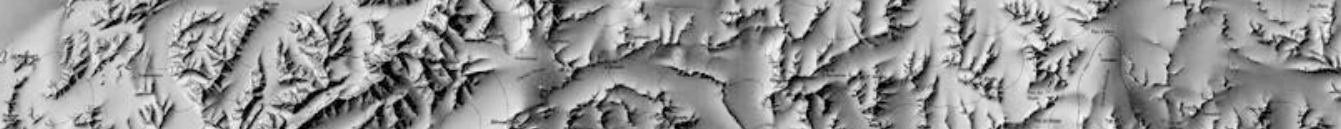
-

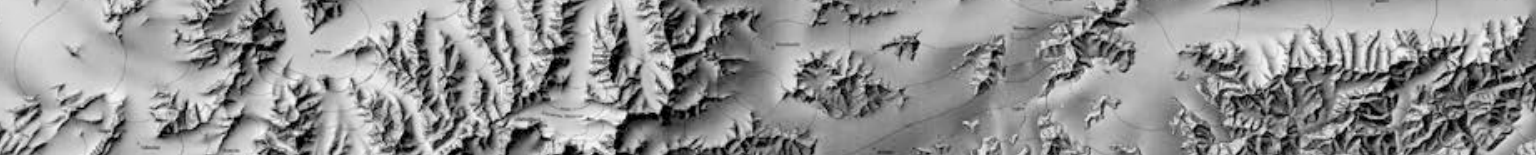
tif a a

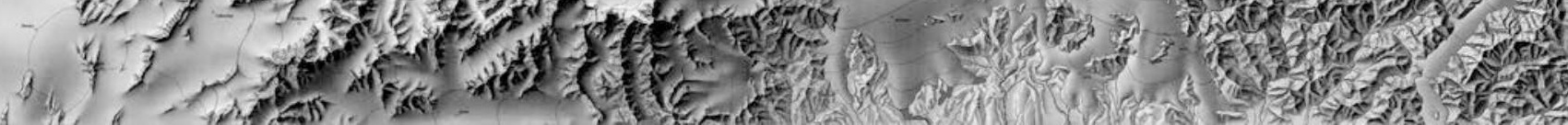



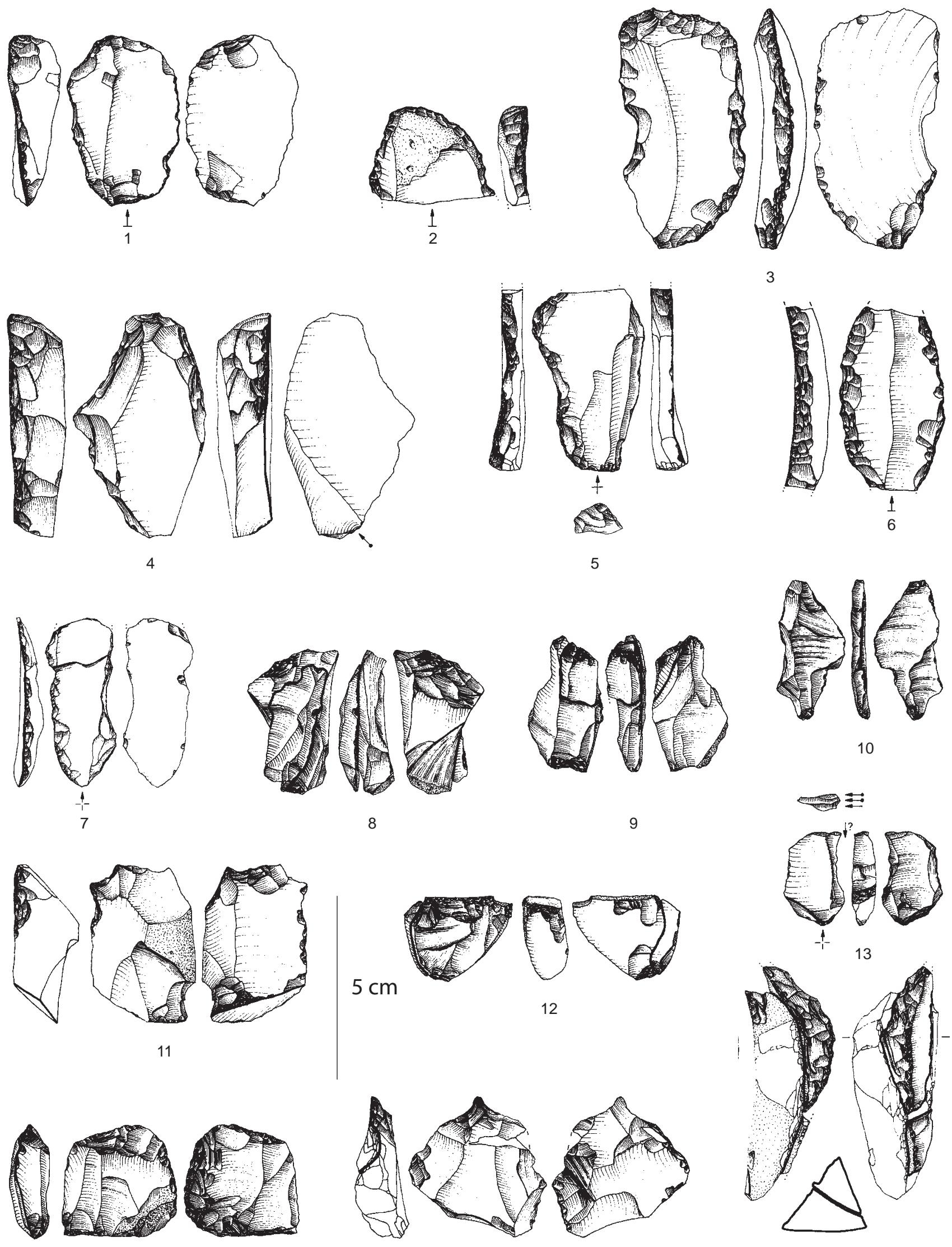

14
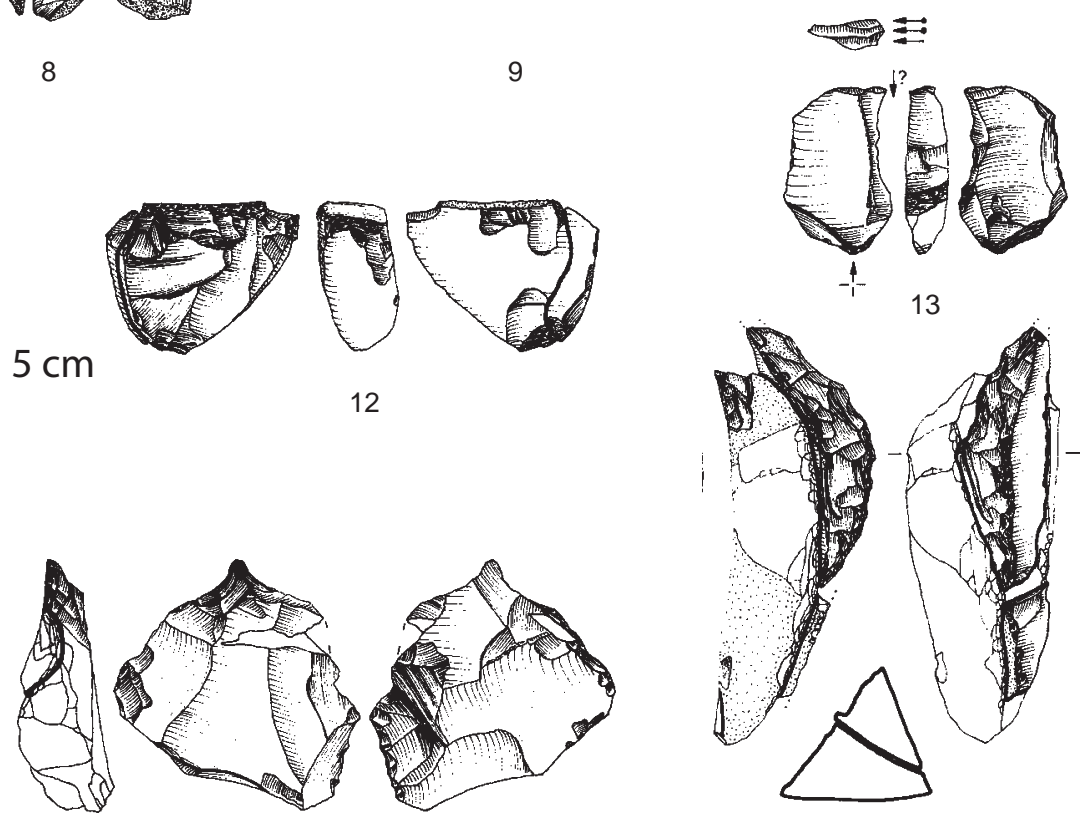

16 


\section{Figure 4}
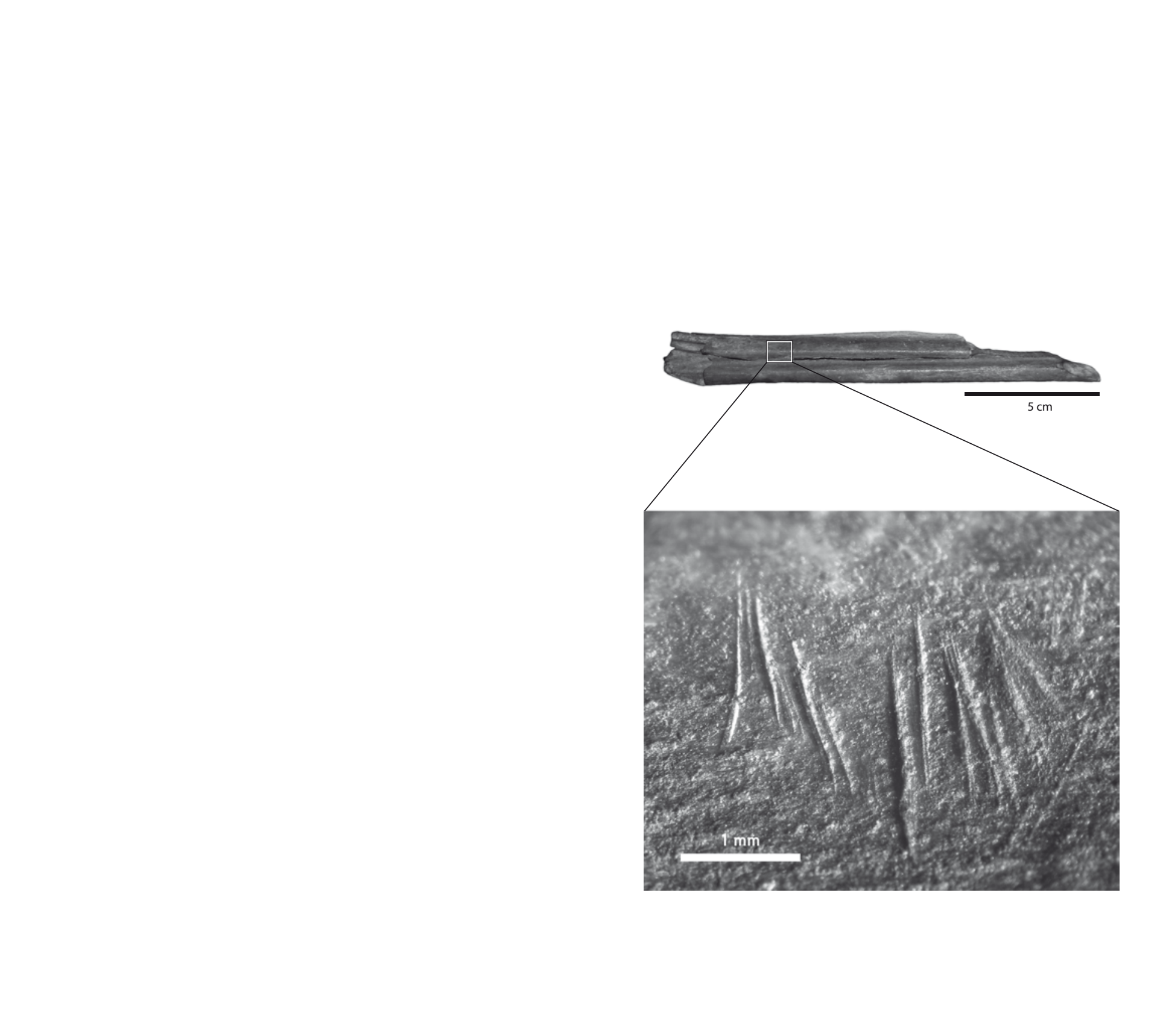

(2)

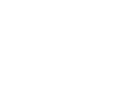
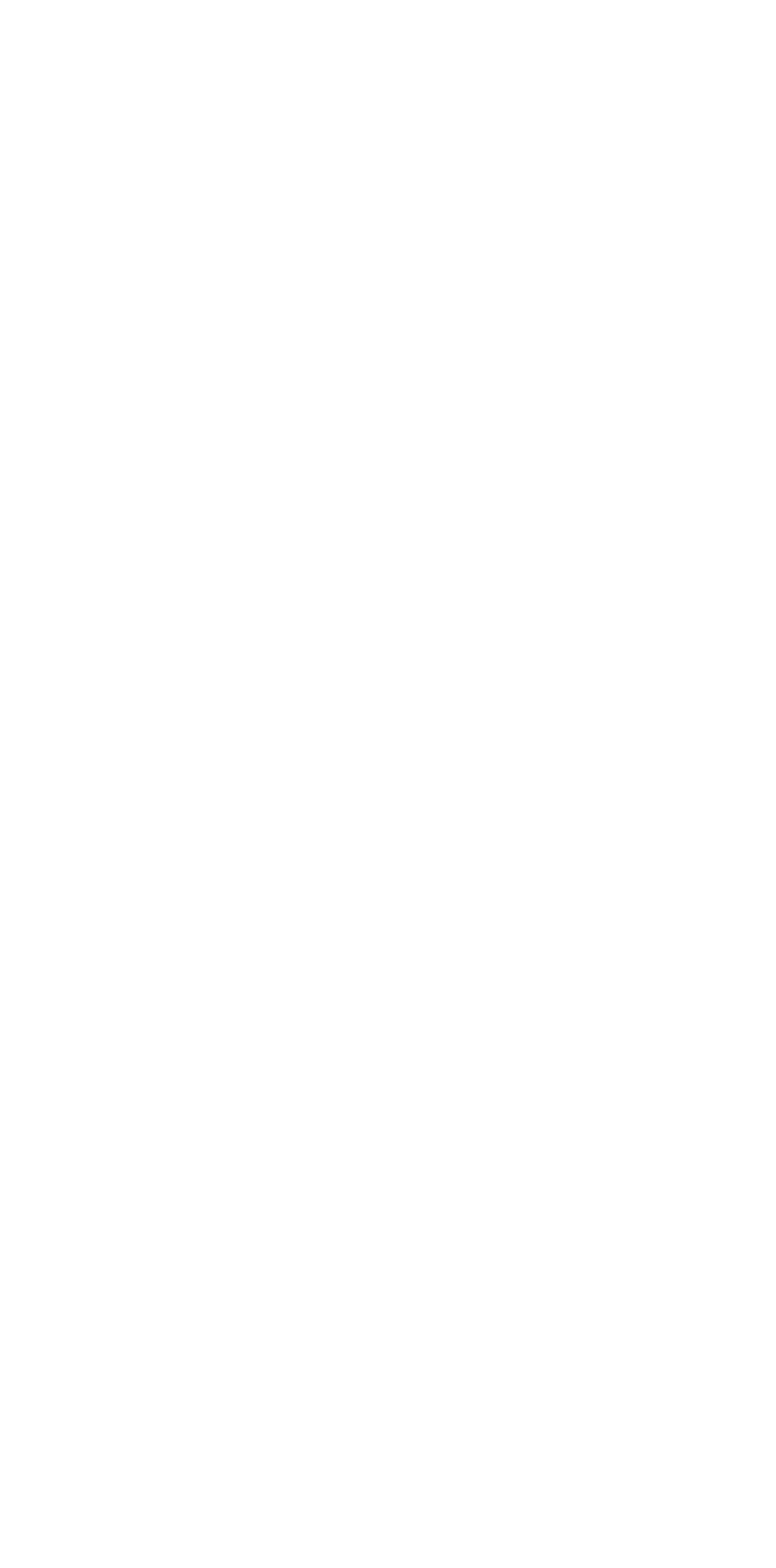

.
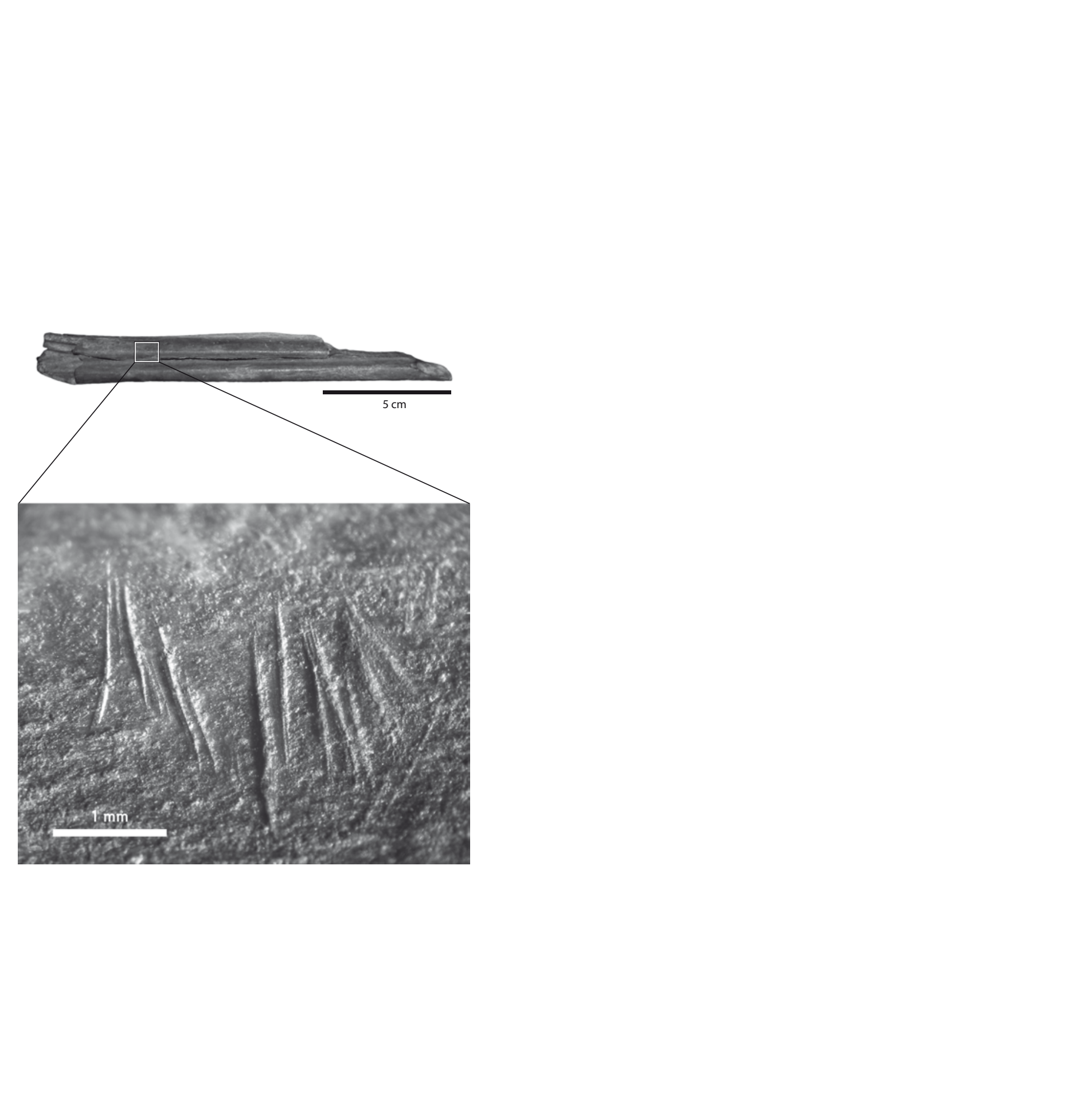


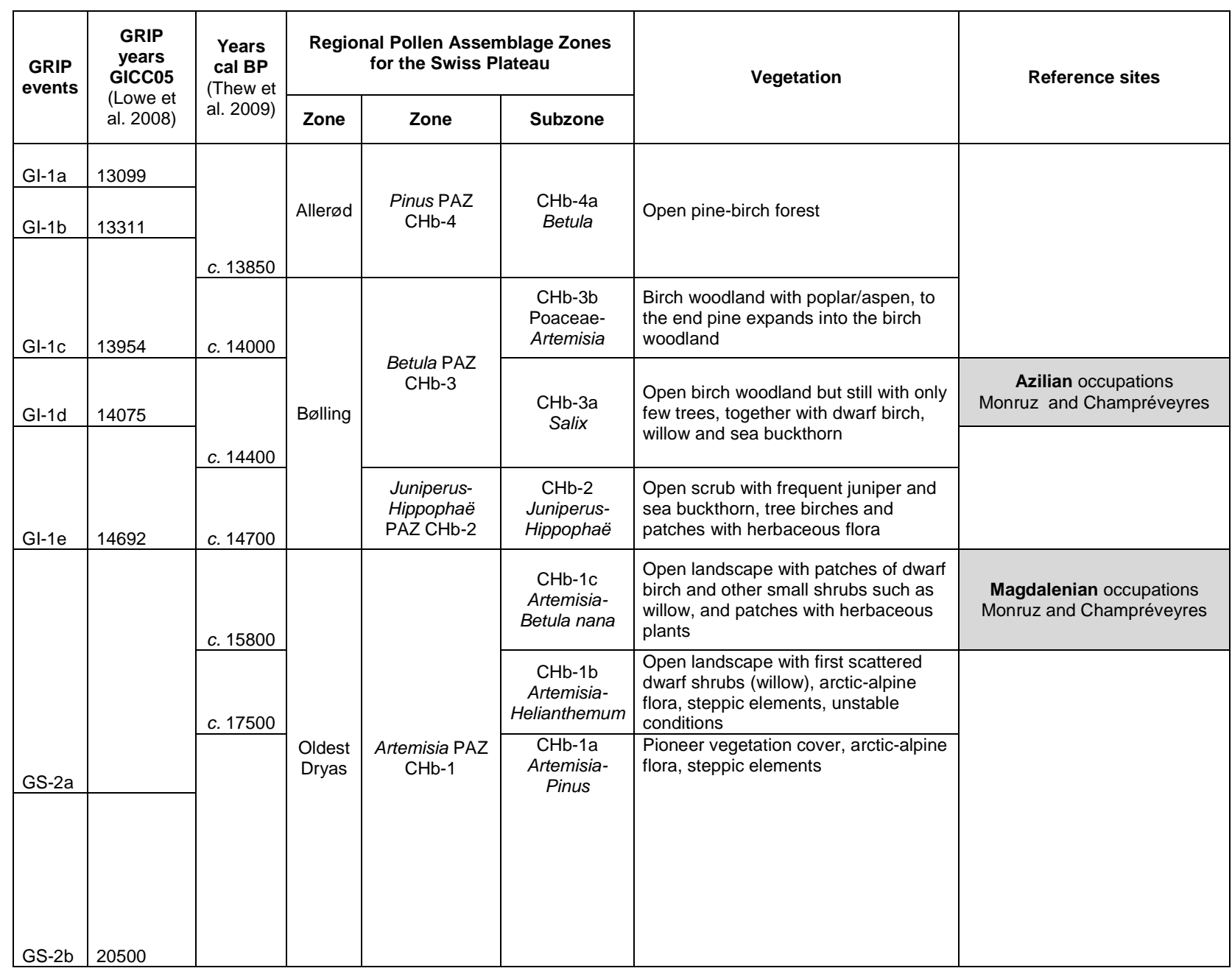




\section{Figure 6}

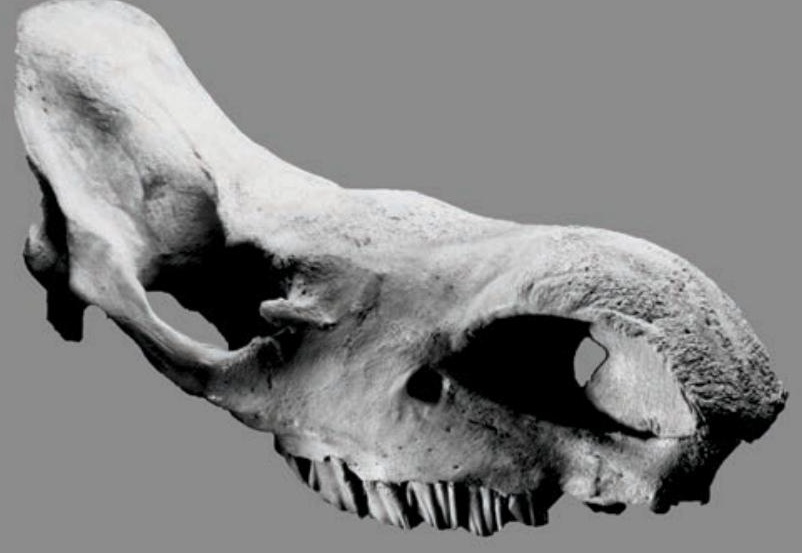

,

.

$$
8
$$




\section{Figure 7}

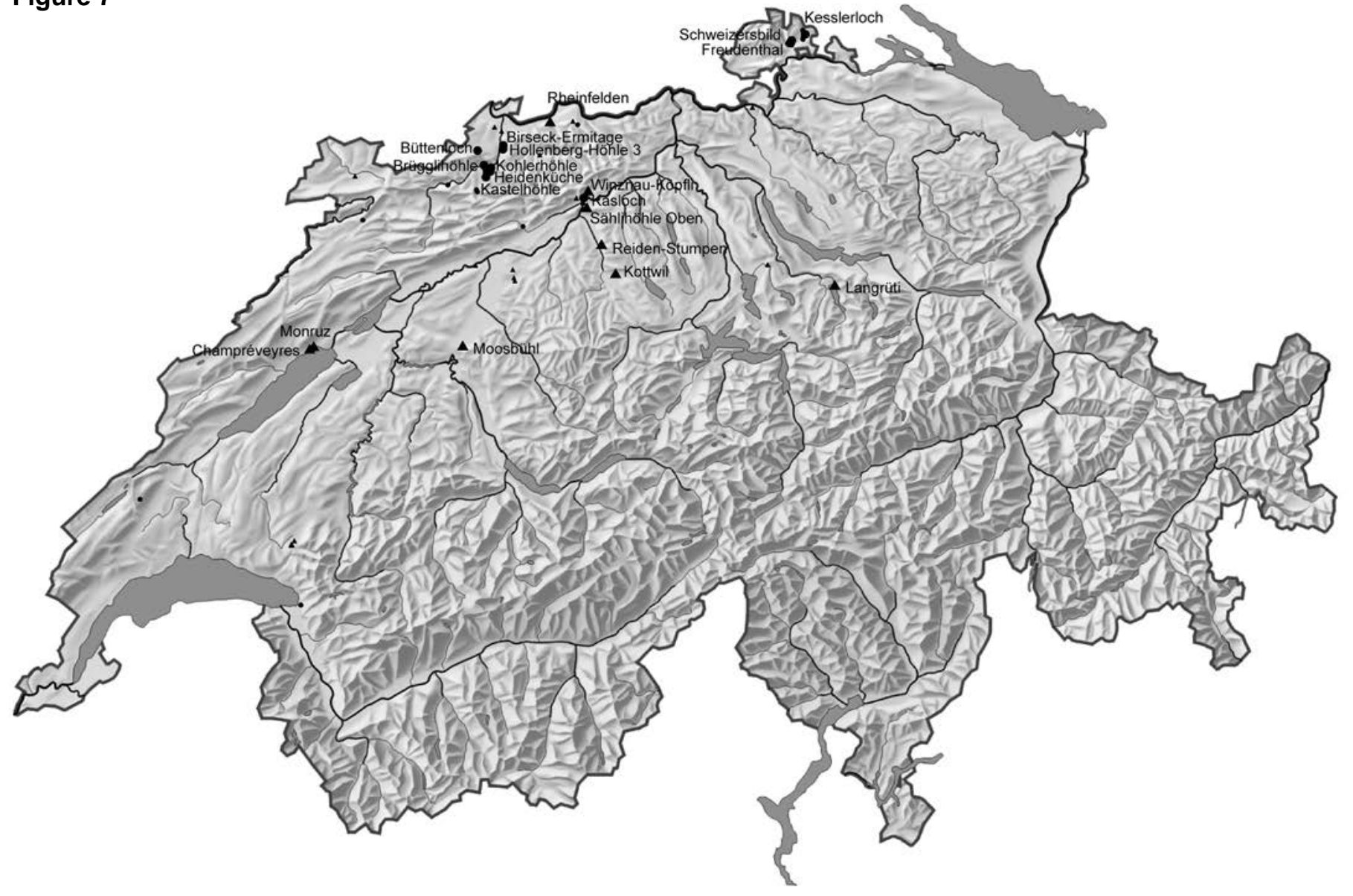


Figure 9
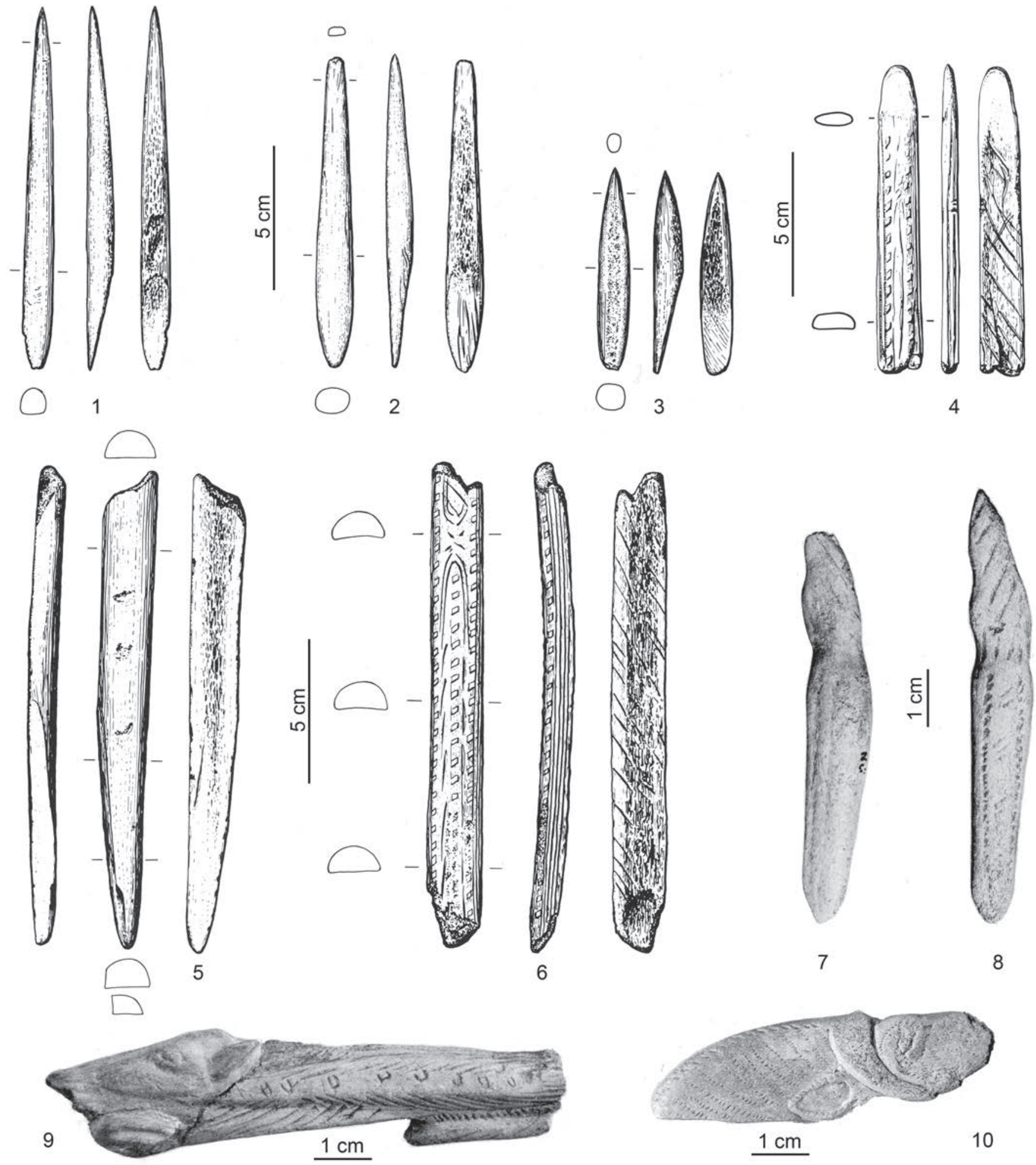
Figure 10
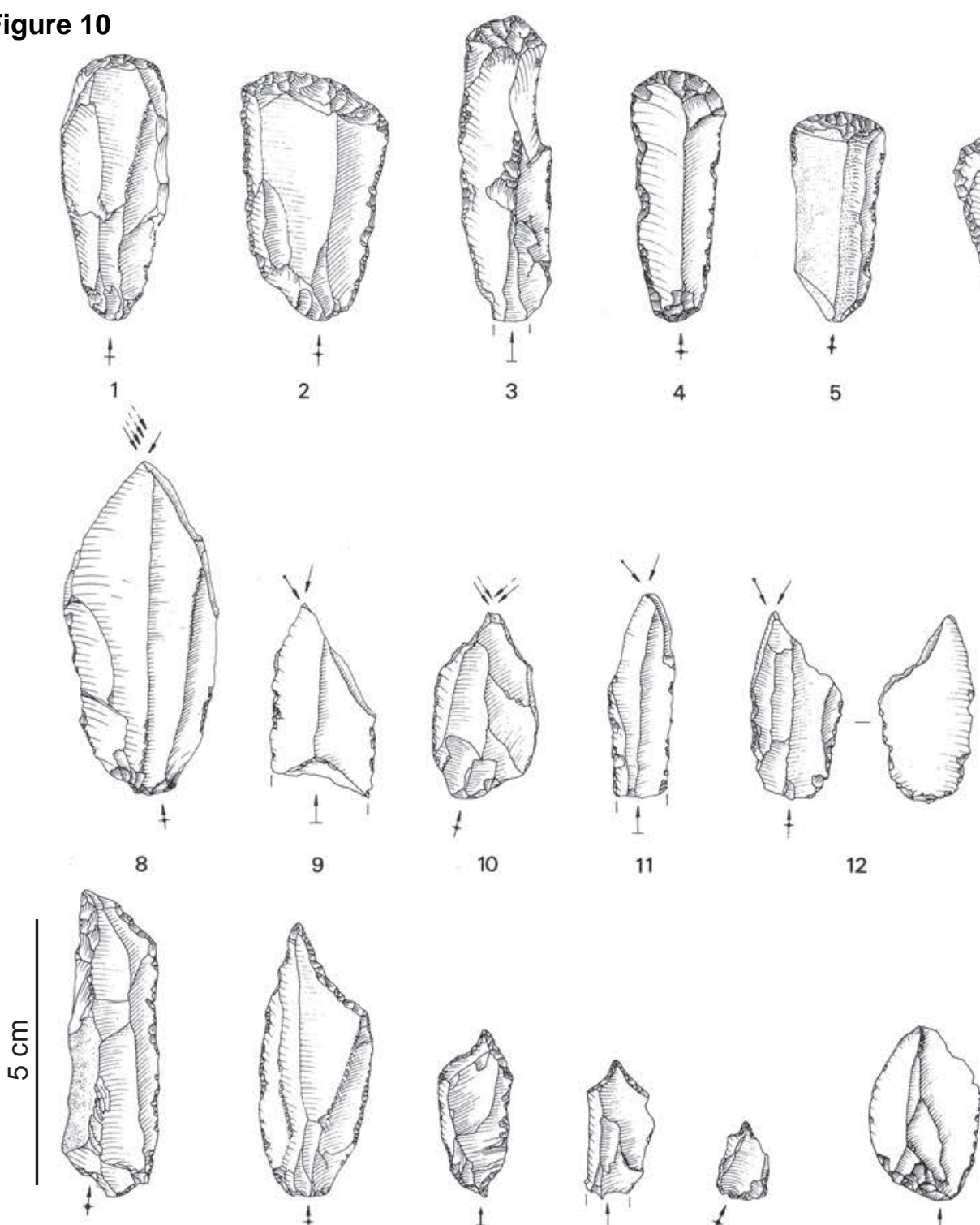

15

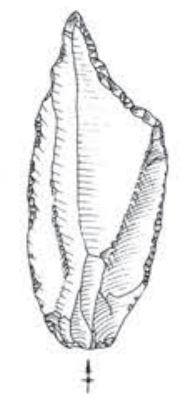

16
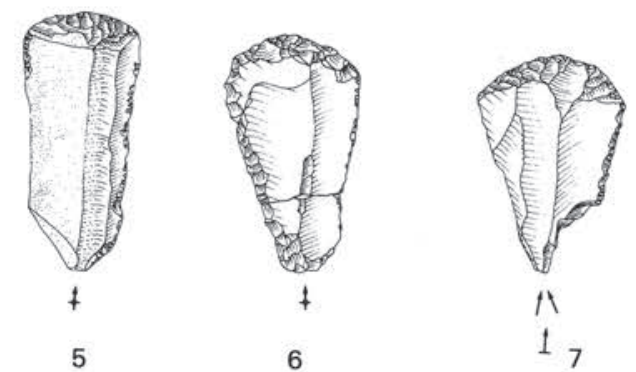

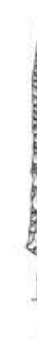
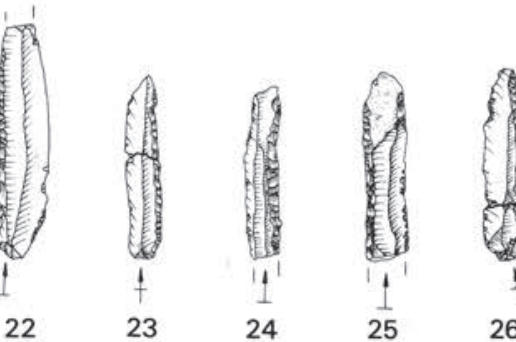

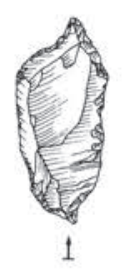

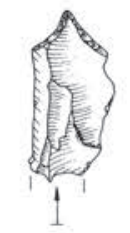

18
17

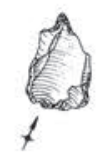

19

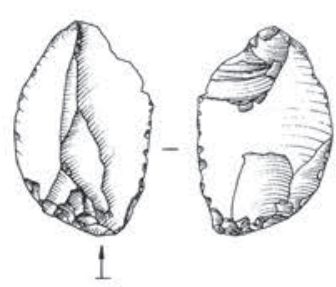

20

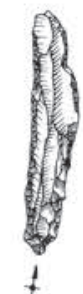

$26 \quad 27 \quad 28$
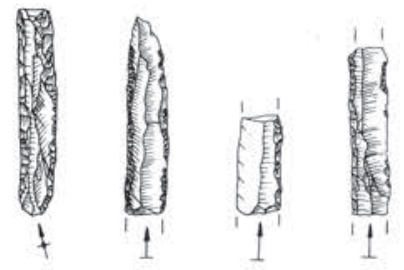

$\begin{array}{llll}29 & 30 & 31 & 32\end{array}$
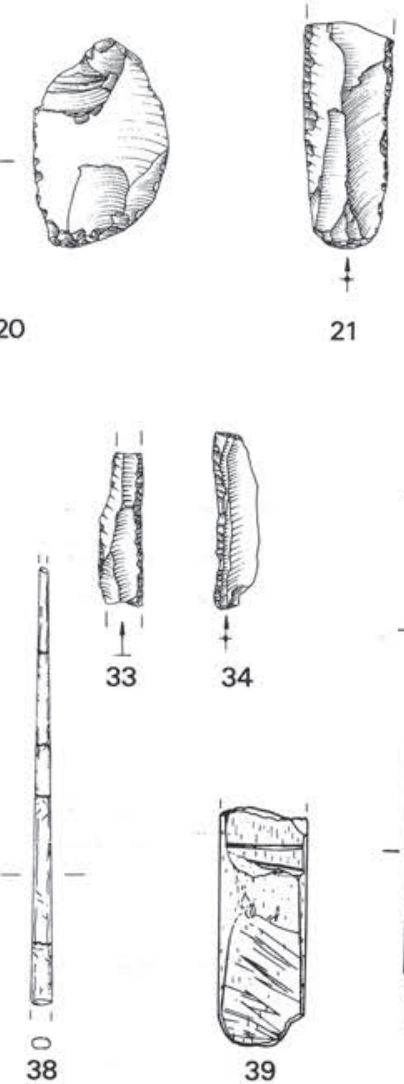

21

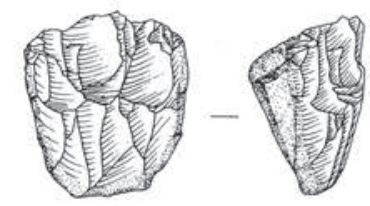

35

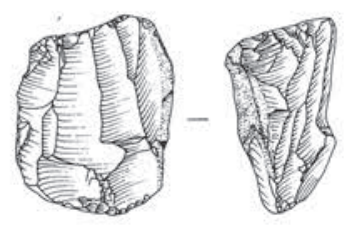

36
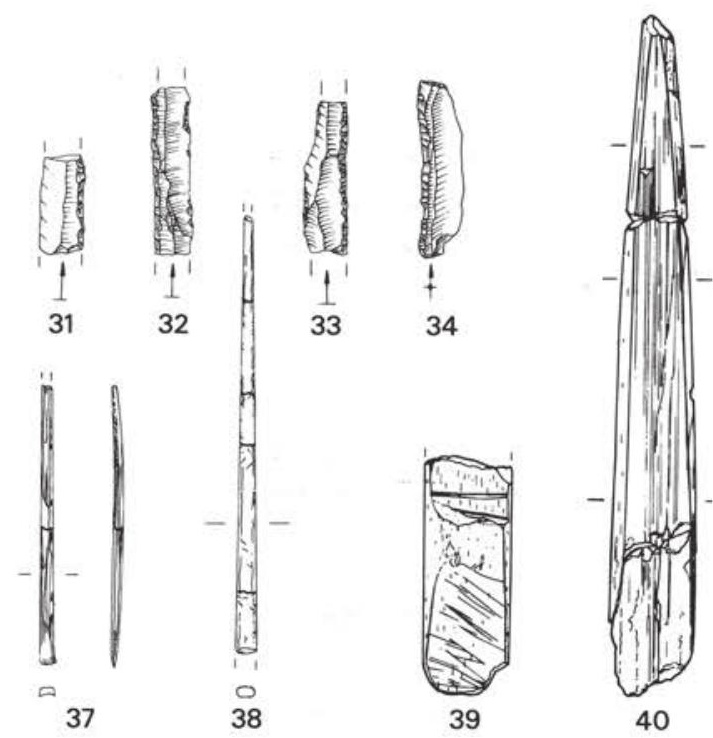


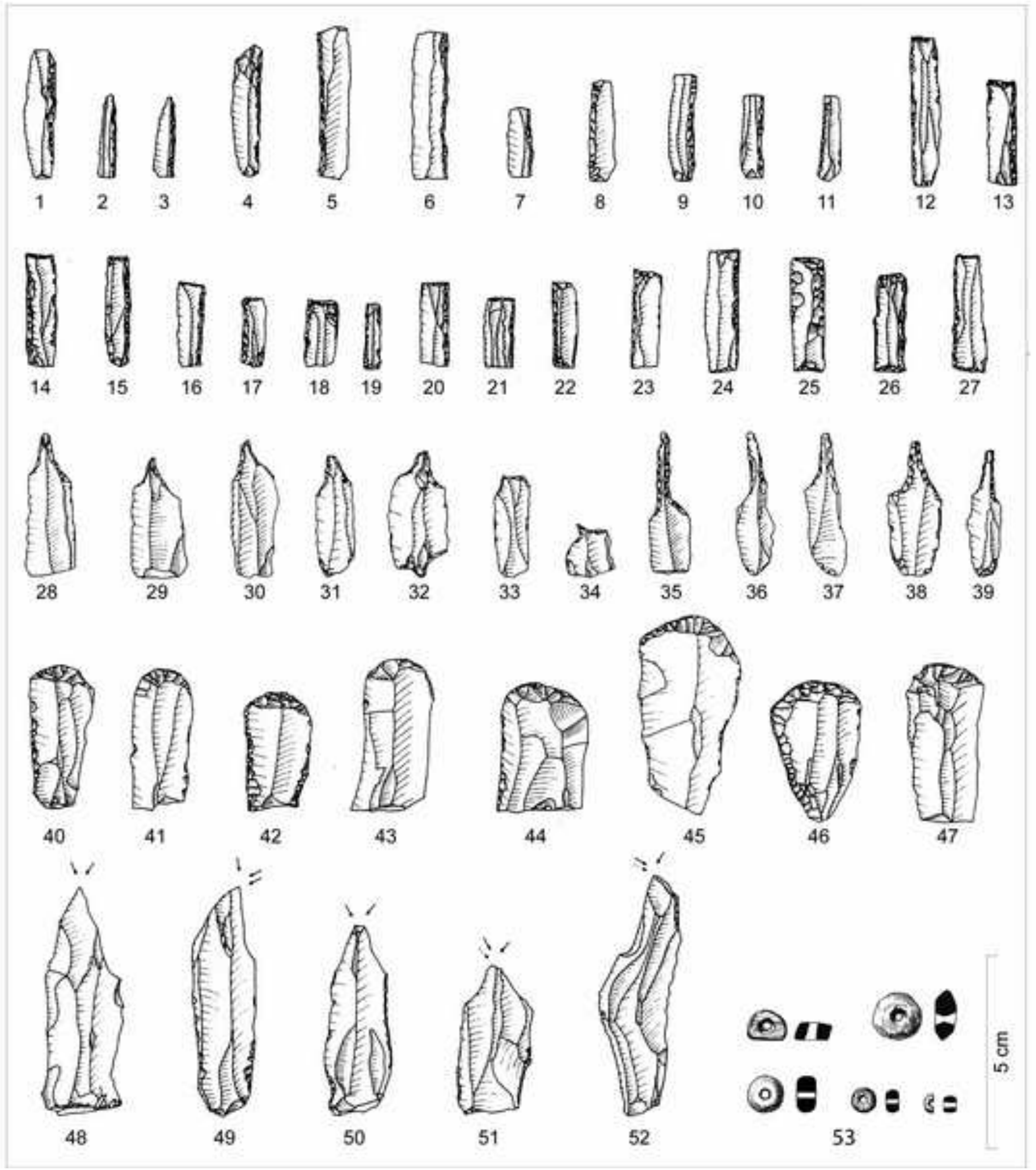



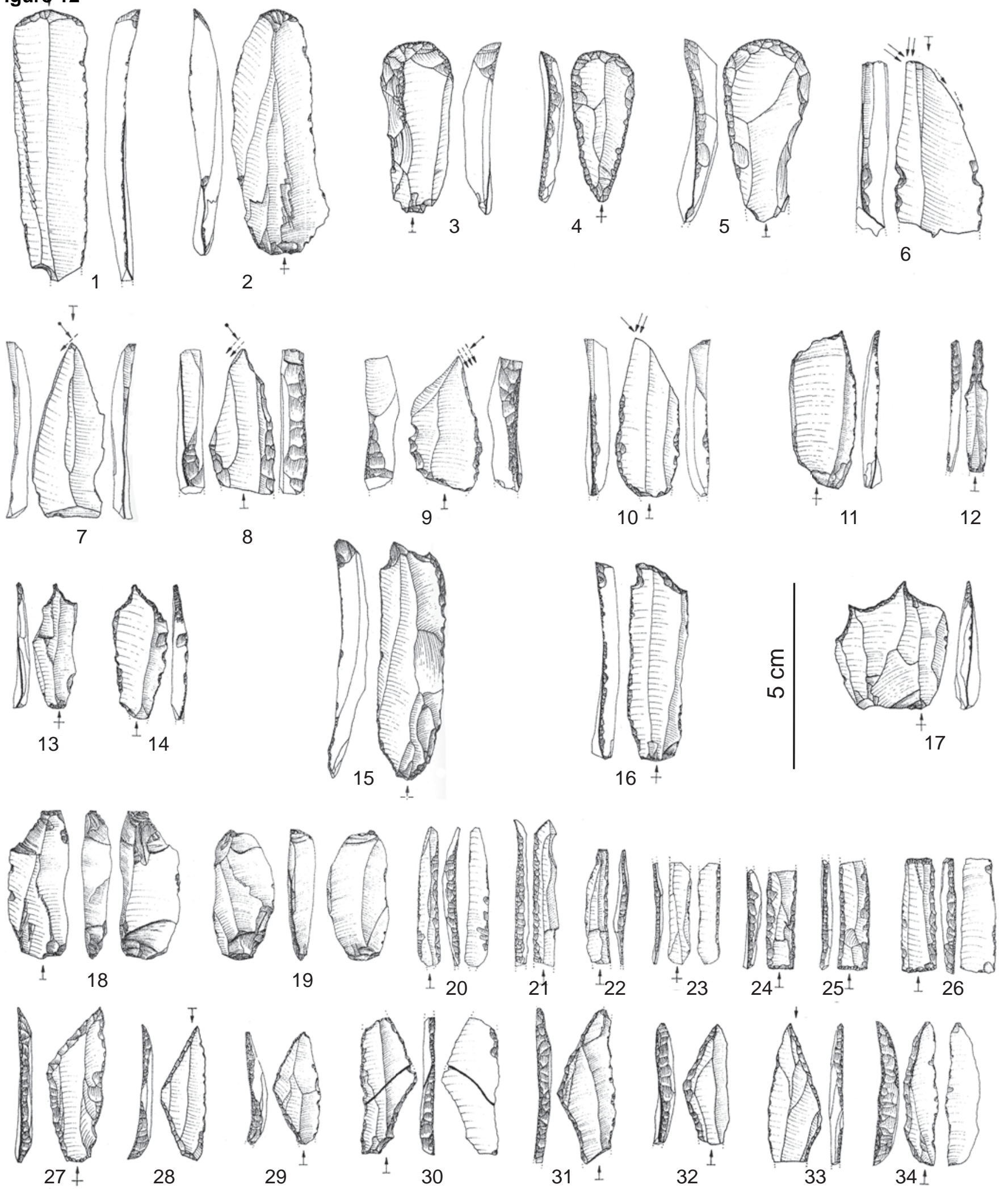

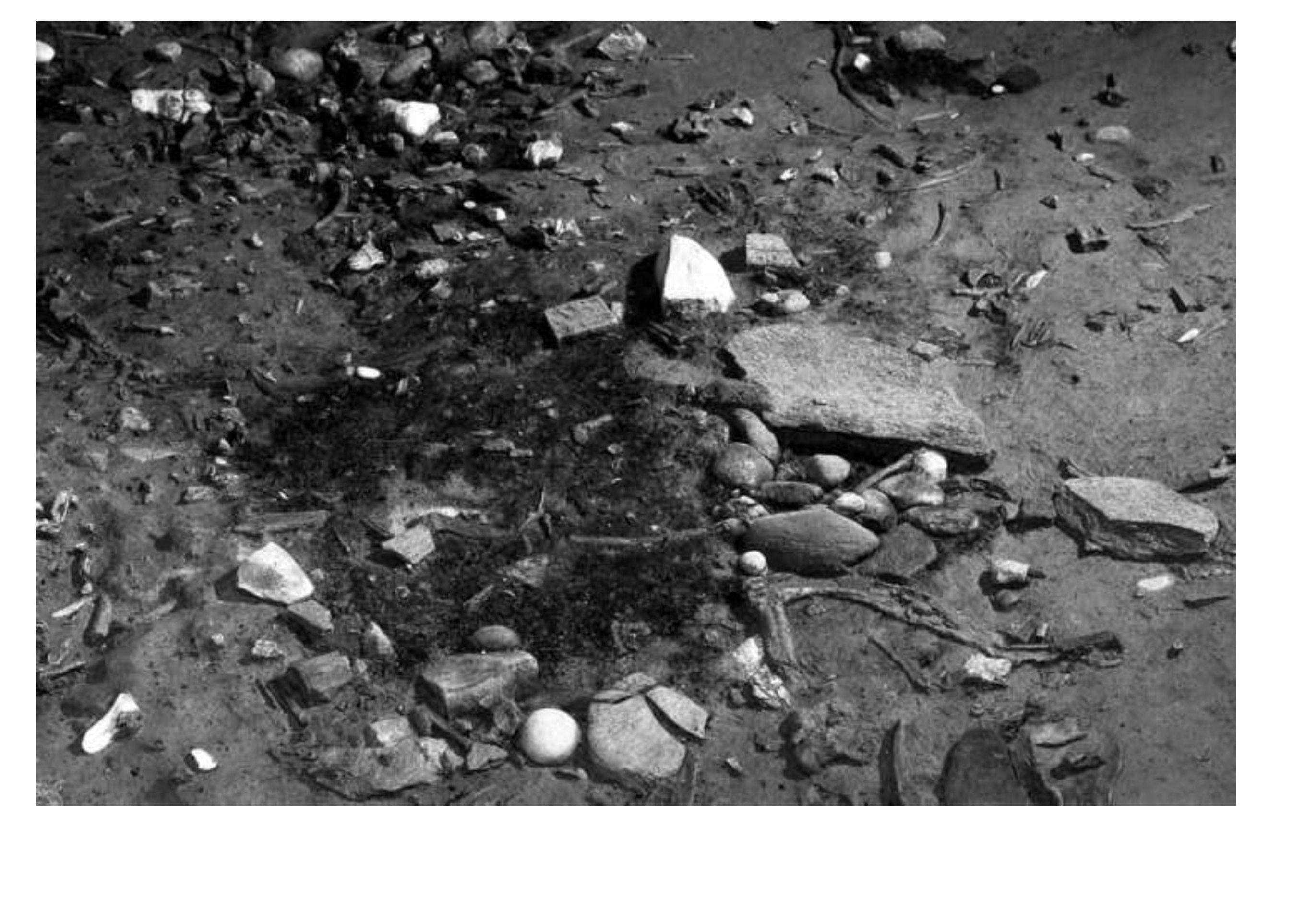
Click here to download high resolution image

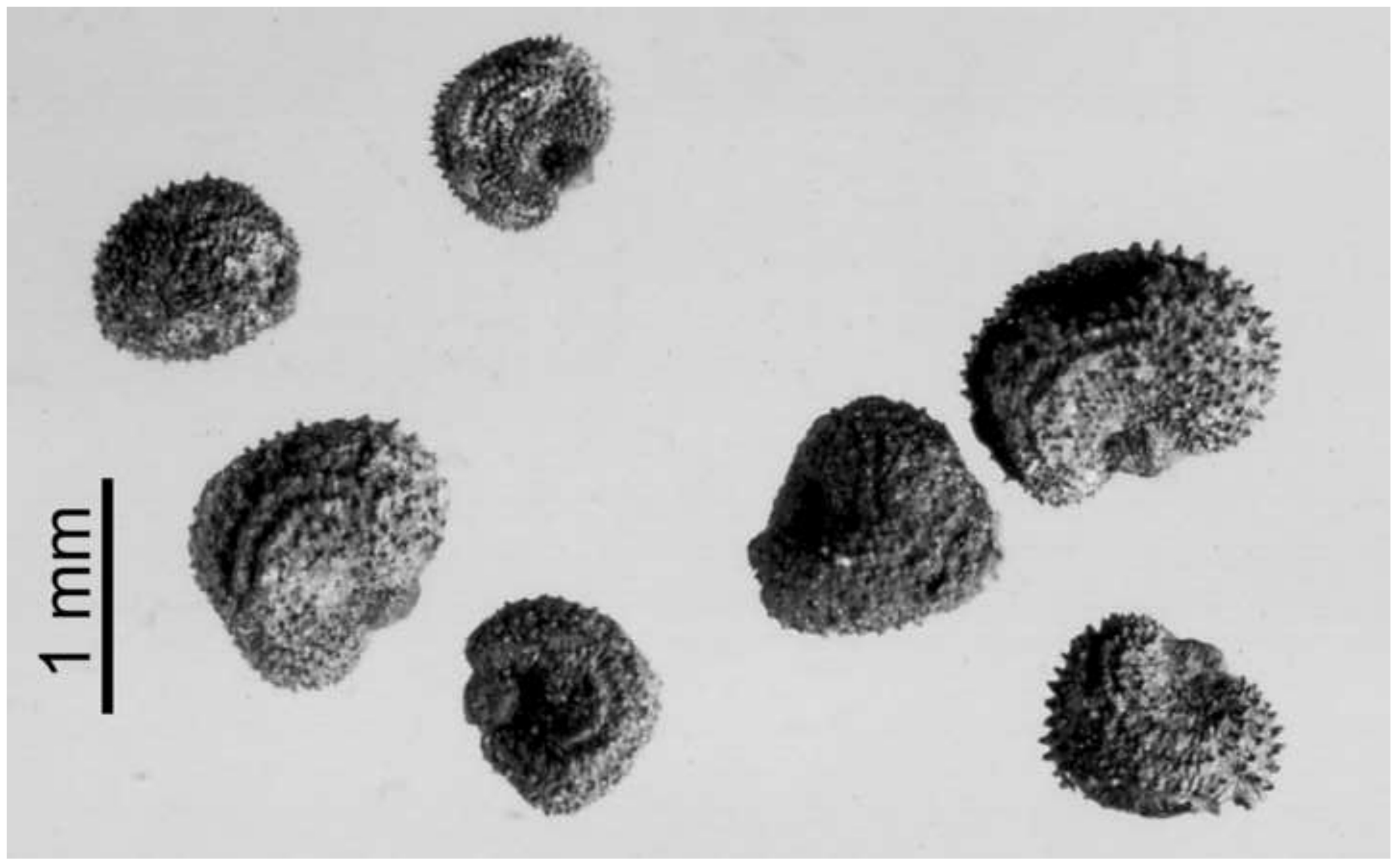




\begin{tabular}{|c|c|c|c|c|c|c|}
\hline Site & Lab. number & ${ }^{14} \mathrm{C}$ yr BP & cal BC $2 \sigma$ & ${ }^{13} \mathrm{C}$ & Species & Reference \\
\hline Birseck-Ermitage, lower layer & ETH-43307 & $11900 \pm 55$ & $11975-11553$ & -14.9 & Rangifer & Leesch \& Müller 2012 \\
\hline \multirow[t]{4}{*}{ Hollenberg-Höhle 3} & Erl-13569 & $12846 \pm 63$ & $13950-13000$ & -18.9 & Rangifer & Müller \& Leesch 2011 \\
\hline & Erl-13570 & $12798 \pm 70$ & $13950-12900$ & -18.3 & Rangifer & Müller \& Leesch 2011 \\
\hline & Erl-13571 & $13114 \pm 71$ & $14600-13200$ & -19.2 & Rangifer & Müller \& Leesch 2011 \\
\hline & Erl-13572 & $13077 \pm 71$ & $14500-13200$ & -18.6 & Rangifer & Müller \& Leesch 2011 \\
\hline \multirow[t]{5}{*}{ Kohlerhöhle, upper layer } & ETH-39760 & $11525 \pm 60$ & $11590-11290$ & -36.0 & Equus & Leesch \& Müller 2012 \\
\hline & ETH-39761 & $12790 \pm 45$ & $13700-12950$ & -22.3 & Equus & Leesch \& Müller 2012 \\
\hline & ETH-39762 & $12465 \pm 40$ & $13100-12200$ & -17.2 & Equus & Leesch \& Müller 2012 \\
\hline & ETH-43309 & $12460 \pm 45$ & $13100-12200$ & -21.6 & Rangifer & Leesch \& Müller 2012 \\
\hline & ETH-43310 & $16205 \pm 55$ & $17650-16950$ & -21.1 & Rangifer & Leesch \& Müller 2012 \\
\hline \multirow[t]{2}{*}{ Büttenloch, layer B } & UtC-12576 & $12170 \pm 80$ & $12550-11800$ & -17.6 & Lagopus & Leesch \& Müller 2012 \\
\hline & UtC-12577 & $12180 \pm 90$ & $12600-11800$ & -19.4 & Lagopus & Leesch \& Müller 2012 \\
\hline \multirow[t]{2}{*}{ Büttenloch, layer A } & UtC-12574 & $12870 \pm 80$ & $14200-13000$ & -21.2 & Lepus & Leesch \& Müller 2012 \\
\hline & UtC-12575 & $12750 \pm 80$ & $13700-12650$ & -19.9 & Lepus & Leesch \& Müller 2012 \\
\hline Moosbühl, sector VI & ETH-40929 & $7590 \pm 40$ & $6510-6380$ & -31.2 & Rangifer, antler modif. & Leesch \& Müller 2012 \\
\hline \multirow[t]{2}{*}{ Champréveyres, sector 1} & OxA-20700 & $12815 \pm 65$ & $13950-12950$ & -20.5 & Equus & Bodu et al. 2009 \\
\hline & OxA-20701 & $12805 \pm 75$ & $14000-12900$ & -20.4 & Equus & Bodu et al. 2009 \\
\hline Monruz, sector 1 & OxA-20699 & $13055 \pm 60$ & $14500-13200$ & -20.3 & Equus & Bodu et al. 2009 \\
\hline \multirow[t]{3}{*}{ Kastelhöhle Nord, upper layer } & ETH-45024 & $13435 \pm 50$ & $14950-14250$ & -18.8 & Bos/Bison & Leesch \& Müller 2012 \\
\hline & ETH-45025 & $12395 \pm 45$ & $13000-12150$ & -18.9 & Rangifer & Leesch \& Müller 2012 \\
\hline & ETH-45026 & $12215 \pm 45$ & $12550-11900$ & -19.8 & Rangifer & Leesch \& Müller 2012 \\
\hline \multirow[t]{5}{*}{ Rislisberghöhle } & ETH-39768 & $10770 \pm 45$ & $10840-10610$ & -21.7 & Equus & Leesch \& Müller 2012 \\
\hline & ETH-42514 & $12235 \pm 45$ & $12600-11900$ & -22.2 & cf. Equus & Leesch \& Müller 2012 \\
\hline & ETH-42515 & $12710 \pm 45$ & $13600-12700$ & -20.5 & Capra ibex & Leesch \& Müller 2012 \\
\hline & ETH-42516 & $12680 \pm 45$ & $13550-12650$ & -20.3 & Cervus & Leesch \& Müller 2012 \\
\hline & ETH-42517 & $13000 \pm 50$ & $14400-13100$ & -19.6 & Rangifer & Leesch \& Müller 2012 \\
\hline \multirow[t]{3}{*}{ Käsloch } & ETH-39769 & $12505 \pm 45$ & $13150-12250$ & -24.9 & Equus & Leesch \& Müller 2012 \\
\hline & ETH-39770 & $13760 \pm 45$ & $15100-14770$ & -19.2 & Equus & Leesch \& Müller 2012 \\
\hline & ETH-39771 & $12450 \pm 45$ & $13050-12200$ & -24.7 & Equus & Leesch \& Müller 2012 \\
\hline \multirow[t]{2}{*}{ Kesslerloch } & KIA-11825 & $12774 \pm 54$ & $13700-12800$ & -22.6 & Equus & Napierala 2008 \\
\hline & KIA-11826 & $12502 \pm 52$ & $13150-12250$ & -20.5 & Equus & Napierala 2008 \\
\hline layer In & KIA-11827 & $13052 \pm 53$ & $14500-13200$ & -20.4 & Equus & Napierala 2008 \\
\hline layer IIIn & KIA-11828 & $13858 \pm 55$ & $15190-14810$ & -21.0 & Equus & Napierala 2008 \\
\hline \multirow[t]{7}{*}{ layer IIc } & KIA-11829 & $12897 \pm 53$ & $14200-13000$ & -18.7 & Equus & Napierala 2008 \\
\hline & KIA-33350 & $12225 \pm 45$ & $12210-11900$ & -17.7 & Canis & Napierala 2008 \\
\hline & KIA-33351 & $12335 \pm 45$ & $12950-12050$ & -18.6 & Cervus & Napierala 2008 \\
\hline & OxA-10238 & $14330 \pm 110$ & $15900-15100$ & -20.0 & Coelodonta & Napierala 2008 \\
\hline & OxA-10239 & $13980 \pm 110$ & $15500-14850$ & -20.4 & Mammuthus & Napierala 2008 \\
\hline & OxA-10298 & $15020 \pm 180$ & $16700-15850$ & -21.1 & Mammuthus & Napierala 2008 \\
\hline & OxA-5746 & $13120 \pm 90$ & $14600-13200$ & -19.9 & Rangifer, antler point & Housley et al. 1997 \\
\hline \multirow[t]{2}{*}{ layer III Bc } & OxA-5747 & $13430 \pm 100$ & $14950-13950$ & -18.9 & Rangifer & Housley et al. 1997 \\
\hline & OxA-5748 & $12770 \pm 90$ & $14000-12600$ & -20.8 & Bone, modified & Housley et al. 1997 \\
\hline \multirow[t]{4}{*}{ layer III Ac } & OxA-5749 & $14150 \pm 100$ & $15650-14900$ & -18.5 & Rangifer, antler modif. & Housley et al. 1997 \\
\hline & OxA-5750 & $13670 \pm 100$ & $15100-14550$ & -19.1 & Rangifer, antler modif. & Housley et al. 1997 \\
\hline & B-3329 & $12970 \pm 180$ & $14700-13000$ & & Rangifer & Albrecht 1982 \\
\hline & Hv-10652 & $12890 \pm 90$ & $14300-13000$ & & bones indet. & Geyh \& Schreiner 1984 \\
\hline
\end{tabular}


$\begin{array}{ll}\text { Date: } & \text { Mar 13, } 2012 \\ \text { To: } & \text { "Denise Leesch" denise.leesch@yahoo.fr } \\ \text { cc: } & \text { terberge@uni-greifswald.de } \\ \text { From: } & \text { "Norm Catto, Editor, Quaternary International" ncatto@mun.ca } \\ \text { Subject: } & \text { Your Submission }\end{array}$

Ms. Ref. No.: QUATINT-D-12-00069

Title: The Magdalenian in Switzerland: recolonization of a newly accessible landscape

Quaternary International

Dear Dr Denise Leesch,

Reviewers have now commented on your paper. You will see that they are advising that you revise your manuscript. If you are prepared to undertake the work required, I would be pleased to reconsider your revised manuscript.

For your guidance, reviewers' comments are appended below.

If you decide to revise the work, please submit a list of changes or a rebuttal against each point which is being raised when you submit the revised manuscript.

To submit a revision, please go to http://ees.elsevier.com/quatint/ and login as an Author. Your username is: $* * * * * *$

On your Main Menu page is a folder entitled "Submissions Needing Revision". You will find your submission record there.

PLEASE NOTE: The journal would like to enrich online articles by visualising and providing geographical details described in Quaternary International articles. For this purpose, corresponding KML (GoogleMaps) files can be uploaded in our online submission system. Submitted KML files will be published with your online article on ScienceDirect. Elsevier will generate maps from the KML files and include them in the online article.

Yours sincerely,

Norm Catto

Editor-in-Chief

Quaternary International

Reviewers' comments:

Reviewer \#1: Is it possible to note the calibrated dates (in parentheses) after each radiocarbon date? It seems quite heavy to indicate both dates systematically, so we added a sentence in section 9 to refer to Fig. 15 where we added a column containing the calibrated dates expressed in cal BC. We also added a reference to an article which will be published in a Swiss journal in June $\mathbf{2 0 1 2}$ and where those dates are presented individually.

Is it possible to add a new column with radiocarbon years in fig. 5 ? Yes, we added the column of the calibrated dates.

On page 5: beveled antler point or bevelled antler point? It is not very clear from the existing literature, but "beveled" seems to be used more frequently.

Reviewer \#3: The manuscript presents a very interesting and valuable study on the re-colonization (I would prefer this spelling) of central Europe during the Magdalenian. The authors present new data to demonstrate that in the northern part of Switzerland human settlement already started at least during the final phase of the Last Glacial maximum which contrasts earlier views that this country was re-settled no earlier than well after the end of the Late Glacial Maximum. This has also important implications for the re-colonization of other parts of central Europe so that the new results presented in the paper are of much more than regional importance. Congratulations to the authors! Spelling has been changed to re-colonization

The presentation of the data is very clear, the argumentation of the authors is well elaborated and 
plausible. In the end, I hardly found anything to be criticized. Nevertheless, five remarks should be given.

1) In the last sentence of the abstract, "long-distance connections with the upper Danube basin, the Mainz basin, the Paris Basin, the Atlantic coast, the Mediterranean and even the Baltic regions" are mentioned. Although in the last paragraph ( p. 9) the authors address long-distance connections which can be inferred from the circulation of specific 'exotic' ornamental/symbolic objects such as molluscs, other ornamental objects, and amber, they do not explicitly mention some of these regions (especially the Mainz basin [though the Rhine valley is mentioned] and the Paris Basin) in their discussion of longdistance connections. Maybe it would be possible to improve a little bit on the very last block of the last paragraph. We made some small changes in the last block.

2) The term 'inventory' is not the correct translation for the 'german' term 'Inventar'. The proper translation is 'assemblage'. Thank you, we corrected it everywhere in the text.

3) I don't think that one isolated scalene triangle from an open-air site (Kottwil: p. 5) is enough to attribute that site to a specific techno-assemblage. Though these tools in the majority of cases appear in assemblages of the 'middle Magdalenian', they can also be found in other phases of the Magdalenian. Not all authors agree with this comment, but we think that the hypothesis is rather carefully formulated so we left it in the text and added one more reference to the publication of the triangle.

4) No specific mention is made of the personal ornaments from Moosbühl shown in Figure 11. I think they would deserve being mentioned. Has been added in the text, as well as a reference to the illustration (Fig. 11, 53).

5) The paper by Leuzinger-Piccand is given as (Leuzinger-Piccand, 1995) in the text (p. 5) and as Leuzinger-Piccand 1996 in the list of references. Has been corrected in the text. 